\title{
Evaluación de materiales en la zona de la sabana de Bogotá como medios filtrantes para aguas residuales'
}

Evaluation of materials in the area of the sabana of Bogotá as mechanism filters

for wastewater

\author{
Helmut Espinosa García \\ Vilma Hernández Montaña ** \\ Nelly P. Lozano Puentes **** \\ Johana Tavera Tavera ***x+ \\ Alexis Cervera Bonilla \\ Adriana Granja Rodríguez \\ Didier Yagüará ${ }^{* * * * \ldots *}$
}

\section{RESUMEN}

El propósito de la investigación se centró tanto en la evaluación como en la comparación de materiales filtrantes convencionales y no convencionales en sistemas percoladores de aguas residuales. Para ello se realizaron ensayos, en un módulo experimental, sobre el cuerpo hídrico superficial de la quebrada Padre Jesús, en Bogotá D.C. La evaluación se realizó considerando los parámetros físico-químicos de calidad del efluente (en especial el comportamiento de la DQO y la conformación de biofilm).

\section{Palabras clave:}

Filtros percoladores, $\mathrm{DBO}_{5}$, DQO, WQI, aguas residuales, materiales filtrantes.

\section{ABSTRACT}

The intention of the investigation was centered in the evaluation and comparison of conventional and non conventional filter materials in percolators residual water filters, for which tests were made in a modulate experimental on the superficial hydric body of the river Padre Jesus in Bogotá

\footnotetext{
1 Proyecto de investigación del grupo Progasp, adscrito a la Tecnología en Gestión Ambiental y Servicios Públicos de la Universidad Distrital Francisco José de Caldas - gservis@udistrital.edu.co.

** Ingeniero Forestal. Director del Grupo de Investigación Progasp de la Facultad del Medio Ambiente y Recursos Naturales.

*** Ingeniera Química. Coinvestigadora. Profesora de Calidad de Aguas. Facultad del Medio Ambiente y Recursos Naturales.

**** Microbióloga Industrial. Coinvestigadora. Profesora de Residuos Líquidos. Facultad del Medio Ambiente y Recursos Naturales.

***** Coinvestigador. Estudiante de Tecnología en Gestión Ambiental y Servicios Públicos y Tecnología en Saneamiento Ambiental.

***** Coinvestigador. Estudiante de Tecnología en Gestión Ambiental y Servicios Públicos y Tecnología en Saneamiento Ambiental.

****** Coinvestigador. Estudiante de Tecnología en Gestión Ambiental y Servicios Públicos y Tecnología en Saneamiento Ambiental.

******* Coinvestigador. Estudiante de Tecnología en Gestión Ambiental y Servicios Públicos y Tecnología en Saneamiento Ambiental.
} 
D.C. The evaluation was made considering the parameters physical-chemistries of quality of the effluent, in special the quality of the DQO and the conformation of biofilm.

\section{Key words:}

Percolators filters, DBO5, DQO,WQI, residual water, materials filters.

\section{INTRODUCCIÓN}

Las actividades urbanas y rurales de los asentamientos poblados generan, como resultado de su actividad metabólica, concentraciones de aguas residuales que por lo general son descargadas sobre los cuerpos naturales superficiales. En consecuencia, los desechos superaran la capacidad de resiliencia natural y se conforman focos de contaminación que, paulatinamente, se propagan y ponen en riesgo la salud humana y el ecosistema (en sus flujos y cadenas energéticas y tróficas).

La anterior es una situación frecuente en la sabana de Bogotá; en ella se llevan a cabo diferentes procesos extractivos mineros tanto a cielo abierto como de socavón: obtención de arenas finas, carbones y arcillas que, posteriormente, son sometidos a procesos de calentamiento para su transformación en lozas, carbones activados y otros productos de construcción y de aplicación industrial. Como resultado de éstas transformaciones industriales se generan residuos minerales cuya disposición a cielo abierto ocasiona focos de contaminación hídrica o contribuye a la degradación de las corrientes - acelerando la sedimentación.

Por otra parte, las actividades urbanas se han convertido en una problemática significativa en cuanto a la disposición de sustancias de biodegradación lenta, pues son producidas a partir de polímeros plásticos cuyo destino final, en la mayoría de los casos, terminan siendo los rellenos sanitarios (sin que se puedan establecer alterna- tivas de manejo ante su alto volumen y bajo nivel de reincorporación como subproducto o producto). Éste es el caso de materiales como el poliuretano, el icopor y el polietileno de baja densidad; sus niveles de recuperación son bastantes bajos.

Considerando tanto la disposición inadecuada de los materiales residuales no biodegradables como los desperdicios de la industria minera extractiva de la región nororiental de la sabana de Bogotá $-\mathrm{y}$ sus efectos sobre las corrientes de agua-, el grupo de investigación Progasp, con el apoyo del Centro de Investigaciones y Desarrollo Científico de la Universidad Distrital (Cidc-UD), desarrolló un proceso de investigación experimental que evalúa la utilidad de los materiales residuales mencionados en los procesos de filtración de aguas residuales.

Para el desarrollo de la investigación se diseñó un prototipo de batería filtro en la cual se dispusieron, como materiales filtrantes, algunas sustancias de origen mineral y polímeros plásticos. Los ensayos propuestos quisieron establecer diferencias entre el uso de materiales tradicionales (empleados en los filtros) con la implementación de materiales alternativos (considerados como residuo).

El prototipo del filtro se ubicó en un cuerpo natural contaminado por aguas residuales correspondiente a la quebrada Mi Padre Jesús, ubicada en el área de la sede El Vivero de la Universidad Distrital (cerros orientales de Bogotá). Así mismo, las pruebas químicas se centralizaron en el Laboratorio de Química y Calidad de Aguas de la Facultad del Medio Ambiente y Recursos Naturales de la Universidad Distrital Francisco José de Caldas.

Los resultados obtenidos se compararon, respecto a la utilización de materiales tradicionales como la gravilla y el carbón, y permitieron establecer la factibilidad de ejecutar formas alternas de trabajo con los materiales sometidos a prueba (dados sus costos y la reducción de los impactos en el ambiente, pueden tener una nueva oportunidad de uso). 


\section{OBJETIVOS}

\section{Objetivo general}

Evaluar la eficiencia de los materiales provenientes de la sabana de Bogotá — como medios filtrantes y de soporte para sistemas de tratamiento biológicoa partir de la construcción de un prototipo a manera de filtro percolador. Lo anterior con el fin de analizar su capacidad de soporte y comportamiento en la remoción de materia orgánica mediante una aplicación experimental sobre la quebrada $\mathrm{Mi}$ Padre Jesús —o Zanjón de San Martín— ubicada en Bogotá D.C.

\section{Objetivos específicos}

- Caracterizar las aguas provenientes de la quebrada Mi Padre Jesús como punto de partida para su tratamiento.

- Desarrollar un prototipo de filtro percolador con tres tipos de materiales no tradicionales (residuos de la industria minera y materias sintéticas plásticas no biodegradables) de fácil obtención en la sabana de Bogotá.

- Determinar las condiciones de uso de los materiales evaluados.

- Evaluar el rendimiento del filtro, en comparación con uno convencional, utilizando el agua de la quebrada Mi Padre Jesús.

\section{MARCO TEÓRICO}

\section{Biofilm}

Según Ronzano (1995), la formación del biofilm implica la acumulación de microorganismos (bacterias, hongos, microalgas, etc.) en una interfase que puede ser sólido-líquida, gas-liquida o líquido-líquida. Los biofilms - biocapas - pueden o no cubrir uniformemente el sustrato y como mínimo constan de una capa o múltiples capas de microorganismos vivientes y muertos junto con sus productos extracelulares asociados (heteropolisacáridos, glicoproteínas, lípidos, etc.).

Las bacterias se acumulan sobre las superficies en dos procesos: agregación (adhesión y adsorción) y crecimiento (multiplicación celular). Además, durante su evolución, éstos microorganismos desarrollaron mecanismos de adhesión hacia cualquier material natural o sintético. Incluso, los materiales que presentan tensiones bajas, tales como el teflón y los plásticos hidrofóbicos, son susceptibles de colonización bajo algunas condiciones fisicoquímicas (Ronzano, 1995).

Las bacterias presentes en la biocapa obtienen carbono y energía para su crecimiento a partir de la materia orgánica disuelta en el agua de alimentación (carbono orgánico asimilable o COA); no obstante, los nutrientes adsorbidos también pueden ser movilizados y barridos directamente de las superficies. Las materias orgánicas absorbidas suministran niveles mayores de nutrientes a las células en comparación con las presentes en la corriente de fluido bruto. Así pues, la adhesión se reconoce como una estrategia efectiva de supervivencia desarrollada por los microorganismos para competir en condiciones extremas. Las mediciones de COA, por su parte, son fundamentales para la biocapa; proporcionan una indicación de probabilidad acerca de su formación y extensión ${ }^{2}$.

Según Fuster $(2004)^{3}$, cualquier microorganismo, en general, puede producir un biofilm en condiciones adecuadas; sin embargo, algunos presentan mayor predisposición. Los productores más comunes de biofilms pertenecen a los géneros Bacillus (contaminantes habituales del medioambiente), Enterobacteriaceae (contaminantes fecales), Pseudomonas (contaminantes habituales

2 Tratamiento del agua por procesos de membrana / Principios, procesos y aplicaciones. American Water Works Association. Research Foundation. Mc Graw Hill. 1998. p.129-133.

3 Fuster Valls, Núria. Observatori de la Seguretat Alimentària. Universitat Autònoma de Barcelona. 2004. Disponible en: http://www.consumaseguridad.com/web/es/ investigacion/2004/06/02/12636.php 
del agua y alterantes frecuentes de los alimentos proteicos, especialmente de los de origen animal) y Staphylococcus (contaminantes de la piel de animales y humanos).

\section{Clasificación de la actividad biológica}

Para Romero (2002)4, existen varias formas de clasificar las múltiples formas de vida presentes en las aguas a tratar. Según las necesidades de éste trabajo se mencionarán sólo dos:

- Circulantes libres: organismos que tienen alguna movilidad para nadar y buscar alimentos pero que no se fijan, por sí mismos, a las superficies (esféricos, cilíndricos, etc.).

- Organismos sedentarios: se adhieren en forma natural a las superficies de masa creciente - formando biopelículas. Así mismo, todas las demás partículas suspendidas en circulación permanecen sobre éstas células pegajosas (algunas se adhieren a la lama). Con el tiempo, más células formadoras de lama crecen en la masa y, eventualmente, una capa de lama (o biopelícula) se forma sobre toda la superficie ${ }^{5}$.

Los otros sólidos circulantes, incluyendo las bacterias libres, también se adhieren a la biocapa y son consumidos. Incluso, mediante ésta acción, bacterias y nutrientes son "filtrados" — del agua de recirculación - por la lama que ha crecido, hecho que ocasiona una baja densidad de población de bacterias libres circulantes (aunque el sistema esté gravemente sucio por la presencia de biopelícula) ${ }^{6}$.

4 Romero, J.. Tratamiento de aguas residuales. Teoría y Principios de Diseño. Ed. Escuela Colombiana de Ingeniería. 2002.

5 Op.,cit. Romero (2002).

6 Instructivo del analizador Biotech $\mathrm{HMB}$ para bacterias en aguas de enfriamiento. http://www.biotechintl.com INST RUCTIVO\%2520DEL\%2520ANALIZADOR\%2520BioT ech\%2520HMB\%2520PARA\%2520BACTERIAS\%2520E N\%2520AGUAS\%2 0 DE\%2520ENFRIAMIENTO.html Enero 2000

\section{Biofiltración}

Los biofiltros son uno de los componentes de sistemas de tratamiento de aguas residuales que se basan en procesos biológicos y funcionan a partir de la formación de una película bacteriana. Son empleados, principalmente, para la eliminación de sustancias orgánicas biodegradables (Arias, $2004)^{7}$.

En los biofiltros tradicionales, el agua residual es depositada sobre un lecho de piedra, que es un medio permeable al que los microorganismos se adhieren y a través del cual se filtra el agua residual. Según Arias 8 , el tamaño de las piedras que conforman el medio filtrante oscila entre $2.5 \mathrm{~cm}$ y $10 \mathrm{~cm}$ de diámetro; su profundidad varía de acuerdo al diseño particular de $0,9 \mathrm{~cm}$ a $2,4 \mathrm{~m}$; y el promedio de profundidad es de $1,8 \mathrm{~m}$.

Ciertos filtros percoladores utilizan medios filtrantes plásticos con profundidades de $9 \mathrm{~cm}$ a $12 \mathrm{~m}$. El lecho del filtro es de forma circular y el residuo líquido se reparte por encima de éste mediante un distribuidor giratorio. Cada uno de los filtros posee un sistema de desagüe inferior el cual recoge el agua tratada y los sólidos biológicos que se han separado del medio. Cabe resaltar que también permite la circulación de aire.

\section{Sustratos}

Son medios utilizados en los sistemas de película biológica para brindar un soporte sólido y estable a la lama formada, ya que permiten exponer al aire la área máxima superficial del líquido a tratar. Los tipos de medios usados comúnmente se pueden clasificar en dos grupos (Ronzano, 1992): medios minerales - convencionales - y medios especialmente fabricados (construidos generalmente con materiales plásticos). Los medios plásticos se denominan, a menudo, medios a alta tasa (hacen

7 ARIAS, Edison. Et al. Tratamiento Secundario De Aguas. Monografias_com.htm. 2003.

8 Op., cit. ARIAS. 2003

9 Op. cit. RONZANO. 1995. p 192 


\section{TABLA 1. Principales eventos en el proceso de formación de la biocapa sobre un sustrato}

\begin{tabular}{|c|c|c|}
\hline EVENTOS & TIEMPO DE AJUSTE* & DESCRIPCIÓN/EXPLICACIÓN \\
\hline Film orgánico primario & Segundos/minutos & $\begin{array}{l}\text { Referido como el acondicionamiento del film. Definido como la adsorción rápida de las macro- } \\
\text { moléculas orgánicas disueltas y de las sustancias inorgánicas en la interfase membrana/líquido. }\end{array}$ \\
\hline $\begin{array}{l}\text { Adhesión primaria de la } \\
\text { célula }\end{array}$ & Segundos/minutos & $\begin{array}{l}\text { Referido a la agregación bacteriana pionera dependiendo de la naturaleza de: la superficie de la } \\
\text { célula, el tipo de membrana y la química del agua de alimentación e hidrodinámica del sistema. } \\
\text { Suministra una contribución mayor a la acumulación temprana del biofilm (biocapa). }\end{array}$ \\
\hline Desprendimiento celular & Segundos/minutos & $\begin{array}{l}\text { Influye en la tasa de acumulación de la biocapa; el desprendimiento a veces aumenta debido a } \\
\text { agentes microbianos, dispersantes, etc. }\end{array}$ \\
\hline $\begin{array}{l}\text { Crecimiento/ multiplicación } \\
\text { celular }\end{array}$ & Minutos/horas & $\begin{array}{l}\text { Ocurre a expensas de los nutrientes solubles y del agua de alimentación adsorbida. Puede } \\
\text { proporcionar una contribución mayor a la formación de la biocapa cuando los biocidas no están } \\
\text { presentes. }\end{array}$ \\
\hline $\begin{array}{l}\text { Síntesis de biopolímeros } \\
\text { (SPE) }\end{array}$ & Minutos/horas & $\begin{array}{l}\text { Suministra una mayor integridad estructural al biofilm. Actúa como barrera del transporte reac- } \\
\text { tivo para los biocidas químicos y promueve la concentración y el almacenamiento de nutrientes. }\end{array}$ \\
\hline $\begin{array}{l}\text { Arrastre de partículas/ } \\
\text { coloides }\end{array}$ & Segundos/minutos & $\begin{array}{l}\text { Efecto secundario donde las partículas en suspensión, y el material coloidal, son arrastrados } \\
\text { pasivamente hacia la matriz biopolimérica y los espacios vacíos del interior del biofilm. }\end{array}$ \\
\hline $\begin{array}{l}\text { Adhesión secundaria de la } \\
\text { célula }\end{array}$ & Días/semanas & $\begin{array}{l}\text { Comienza después de la formación primaria de la biocapa debido a que las células pioneras inva- } \\
\text { den el medio. Probablemente está muy influida por las propiedades superficiales y la fisiología } \\
\text { de la biocapa primaria. Contiene una diversidad de especies mayor. }\end{array}$ \\
\hline Desprendimiento del biofilm & Días/semanas & $\begin{array}{l}\text { Se refiere al desprendimiento de células y biomasa; ocurre en respuesta a cambios en la tensión } \\
\text { hidrodinámica, fuerzas de turbulencia, introducción de biocidas, dispersantes, etc. }\end{array}$ \\
\hline Obsolescencia de la biocapa & Semanas/meses & $\begin{array}{l}\text { Se refiere a la muerte acelerada de las células en las biocapas viejas (la muerte de la célula está } \\
\text { en equilibrio con el crecimiento de la biocapa en los sistemas de caudal continuo). Puede resultar } \\
\text { de la disminución de los nutrientes solubles vía «lisis» de la célula. }\end{array}$ \\
\hline
\end{tabular}

* Se refiere al tiempo desde que el sustrato es puesto en operación.

Fuente: Modificado de Consejería de Agricultura y Pesca, Junta de Andalucía. Tratamiento del agua por procesos de membrana / Principios, procesos y aplicaciones. American Water Works Association. Research Foundation. Ed. Mc Graw Hill. 1998.p.160

referencia a la carga del sistema; aparte de los soportes plásticos, algunos medios minerales "convencionales" se utilizan en gran cantidad de en tratamientos.

Los medios con altos valores específicos superficiales tienden a poseer espacios intersticiales angostos y son apropiados para los tratamientos a baja tasa. Por el contrario, los de valores específicos superficiales bajos se caracterizan por tener amplios espacios intersticiales y son apropiados para tratamien- tos a alta tasa ${ }^{10}$. La determinación de un material como sustrato debe contemplar:

- La distribución del tamaño de partículas.

- La estabilidad física.

- Debe ser inerte biológica y químicamente.

- El drenaje.

- La capilaridad.

10 Op. cit. RONZANO. 1995. p. 192

REVISTA CIENTÍFICA / ENERO -DICIEMBRE DE 2010 / No. 12 / BOGOTÁ, D.C. 
- Liviano.

- Debe ser de bajo costo.

- Debe estar disponible ${ }^{11}$.

En los procesos de filtración, los sistemas de medio fijo como el que se configura en los filtros percoladores, ofrecen una alternativa de diseño y seguridad operativa dada su historia de uso en el tratamiento de aguas residuales. Empero, la modelación matemática y/o experimental presenta dificultades de pronóstico frente a las características propias de cada sistema. Dicha situación puede convertirse en una debilidad cuando el efluente tratado no alcanza una calidad preestablecida y aumentan las probabilidades de fallo frente a un parámetro esperado de calidad de agua tratada ${ }^{12}$.

\section{Índices de calidad (WQI)}

El índice de calidad de agua propuesto por Brown es una versión modificada del WQI — desarrollado por la Fundación de Sanidad Nacional de EE.UU. $(\mathrm{NSF})^{13}$ — quien, en un esfuerzo por implantar un sistema para comparar ríos en varios lugares del país, creó y diseñó un índice estándar llamado WQI (Water Quality Index), que en español se traduce como Índice de Calidad del Agua (ICA).

Ésta clasificación es ampliamente utilizada para medir los cambios en la calidad del agua en: $a$ ) tramos particulares de los ríos a través del tiempo y $b$ ) diferentes ríos alrededor del mundo — posibilita su comparación. Por su parte, los resultados pueden ser utilizados para determinar si un tramo particular de dicho río es saludable o no.

11 Calderón. Et al. Los Sustratos. 2003. http://www.drcalderonlabs.com/index. html.

Cervera L. y Cuervo S. Evaluación Económica y Ambiental de las Obras de Restauración Morfológica de la Quebrada Mi Padre Jesús o Zanjón de San Martín. Universidad Distrital Francisco José de Caldas. Bogotá D.C. 2000. Pág. 6.

12 Winkler, M. Tratamiento Biológico de Aguas de desecho.1986. Editorial Limusa. página 338

13 Diario Oficial de la Federación. (1989). Acuerdo por el que se establecen los criterios ecológicos de calidad del agua.CE-CCA-001-89. México.
El índice de calidad del agua permite incluir un cierto número de parámetros usuales en la evaluación de aguas superficiales, pues se enumeran en los criterios ecológicos de calidad del agua (CECCA-001-89). Los índices pueden generarse por medio de ciertos elementos básicos en función de los usos del agua. El ICA, por ejemplo, define la aptitud del cuerpo de agua respecto a los usos prioritarios que éste pueda tener. Dichos índices son llamados "de usos específicos". Para la determinación del ICA intervienen 9 parámetros:

- Coliformes fecales (en NMP/100 mL).

- $\quad \mathrm{pH}$ (en unidades de $\mathrm{pH}$ ).

- Demanda bioquímica de oxígeno en 5 días (DBO5 en $\mathrm{mg} / \mathrm{L}$ ).

- $\quad$ Nitratos (NO3 en mg/L).

- Fosfatos (PO4 en mg/L).

- $\quad$ Cambio de la temperatura $\left(\right.$ en $\left.^{\circ} \mathrm{C}\right)$.

- Turbidez (en FAU).

- Sólidos disueltos totales (en mg/L).

- Oxígeno disuelto (OD en \% de saturación).

\section{Localización de la zona de estudio}

La quebrada Mi Padre Jesús está localizada en el costado occidental de la sede El Vivero de la Universidad Distrital. De acuerdo con Cervera (2000), se originó en la servidumbre existente sobre la antigua vía al Santuario de Guadalupe y, a partir del mismo punto de su nacimiento, existen muchas actividades antrópicas que generan impactos negativos sobre la misma (en gran parte de la quebrada se presenta colmatación del cauce).

En el estudio realizado por Cervera $(2000)^{14}$ se indican las siguientes características: la quebrada $\mathrm{Mi}$ Padre Jesús es una cuenca con un área aproximada de 71 ha. Posee una pendiente promedio de $37,9 \%$

14 Op., cit. Cervera L et al. 2000. Página 32-33 


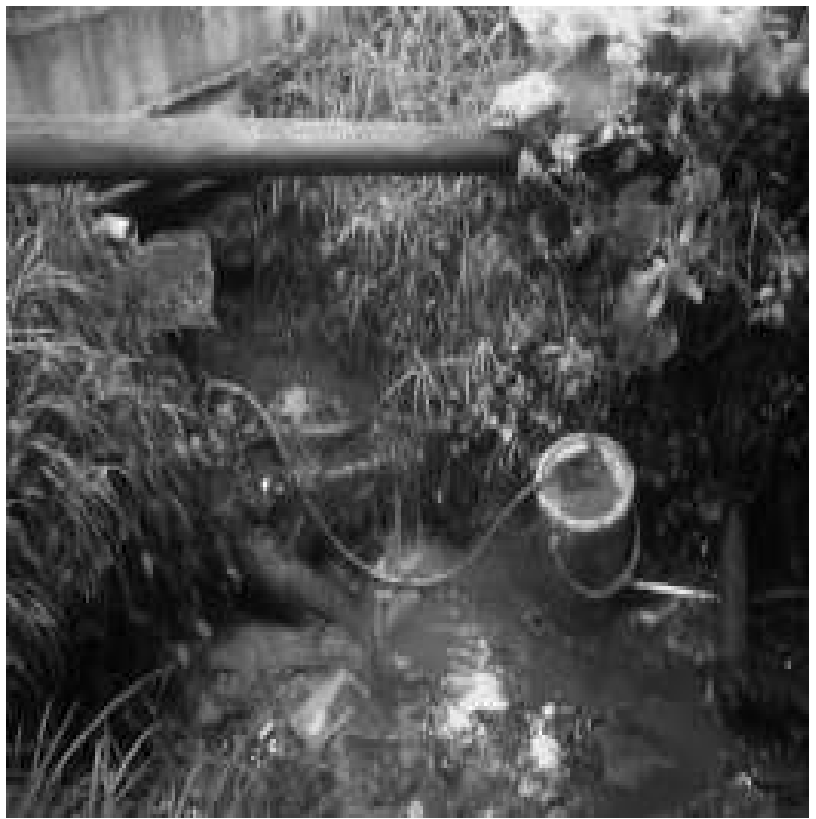

Área de la quebrada Mi Padre Jesús.

y su cauce es angosto tipo escalonado. Así mismo, presenta un régimen de caudal torrencial debido a la alta pendiente por la cual fluyen sus aguas. Se localiza en predios de la Universidad Distrital (sede El Vivero) sobre el costado derecho del carril sur de la Avenida Circunvalar. Dicha zona forma la parte de la microcuenca de la quebrada Padre de Jesús, la cual nace en las estribaciones del Cerro de Monserrate y desemboca en el rio Fucha.

La corriente no presenta un cauce definido; en algunos sitios existe ausencia total de éste o sólo se presentan encharcamientos. Hay diferentes drenajes, los cuales no se entregan correctamente a la quebrada ${ }^{15}$.

\section{ASPECTOS METODOLÓGICOS}

El trabajo se realizó dentro de un enfoque experimental de tipo piloto para probar materiales alternativos (como filtros percoladores) en aguas residuales - partiendo de referentes documentarios sobre criterios de selección del diseño. Para realizar la investigación se establecieron las siguientes etapas:

15 ibid pág-38 a 40

\section{Fase Preliminar}

Etapa de preparación (prediseño de la prueba)

Considerando las similitudes tanto territoriales como socioeconómicas en la zona de influencia de la laguna de Fúquene (Boyacá) con respecto a la de la sabana de Bogotá, se seleccionaron algunos materiales minerales alterados (areniscas, lutitas, residuos de ladrillo, escombros y de la combustión del carbón en hornos). El material control seleccionado como testigo fue la gravilla (considerando los trabajos referenciados en filtraje del mismo) para premodelado del prototipo y muestreo como información preliminar del proyecto.

Luego de las pruebas realizadas a éstos materiales, se descartaron aquellos que no respondieron a los criterios básicos de porosidad y disponibilidad definidos durante el análisis de la información recopilada. Por su parte, a los escogidos se les efectuaron exámenes de: porcentaje de vació (\%), área superficial especifica y densidad (residuos de ladrillo, escombros y combustión del carbón en hornos).

Para facilitar los análisis de laboratorio, de la operación, del mantenimiento y la seguridad del filtro, y de la disminución de los costos por transporte; se optó por construir un prototipo en los predios de la sede El Vivero de la Universidad Distrital (aprovechando la existencia de un cuerpo de aguas afectado por descargas residuales de carácter pecuario y doméstico en el costado sur de la quebrada). Producto de la revisión bibliográfica y la determinación de las condiciones de caudal requeridas para la alimentación de la batería de filtros, en la figura 1 se ilustran los elementos del diseño del prototipo.

El modelo fue constituido por una estructura metálica de $1 \mathrm{~m}$ de largo por $0.9 \mathrm{~m}$ de alto y una base en madera a $0.2 \mathrm{~m}$ que soportó los 3 ensayos. Las características están resumidas en la tabla 2.

El periodo de evaluación preliminar de los materiales filtrantes potenciales en contacto con el afluente de la quebrada Mi Padre Jesús fue de cuatro meses - proceso de maduración de la película de bio-

REVISTA CIENTÍFICA / ENERO -DICIEMBRE DE 2010 / No. 12 / BOGOTÁ, D.C. 
TABLA 2. Características del prototipo de la columna filtro
FIGURA 1. Sistema PRImario de tratamiento y montaje del prototipo de la etapa preliminar.

\begin{tabular}{|l|l|}
\hline Material: & PVC \\
\hline Diámetro: & $4^{\prime \prime}$ \\
\hline Profundidad: & $0.9 \mathrm{~m}$ \\
\hline Tipo de distribución: & Rociador fijo. \\
\hline Forma de aireación: & Convección natural. \\
\hline
\end{tabular}

Fuente: adaptado de Granja y Yaguara (2004).

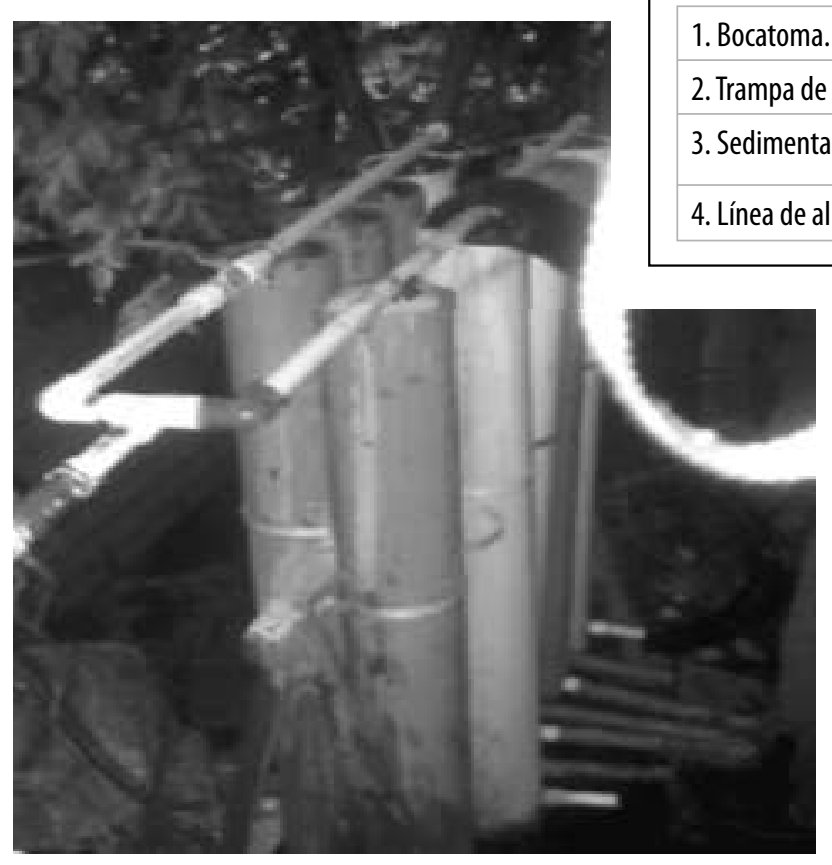

Instalación del prototipo en la quebrada.

film. En seguida se dio inicio a las actividades de muestreo de calidad del agua para los parámetros básicos. Para ello se tomó una muestra de dos litros de agua tratados por cada material filtrante y una muestra testigo; suficiente para los siguientes parámetros: alcalinidad, DQO, $\mathrm{pH}$, temperatura, sólidos totales, sedimentables, suspendidos, disueltos $\mathrm{y}$ volátiles.

Por su parte, para el análisis de las muestras se siguió la metodología indicada en Análisis de aguas, líquidos residuales y ensayos de laboratorio (2000) ${ }^{16}$

16 Camillo G. Y Marciales L. Análisis de aguas, líquidos residuales y ensayos de laboratorio. 2000

REVISTA CIENTíFICA / ENERO -DICIEMBRE DE 2010 / No. 12 / BOGOTÁ, D.C. y en el Manual de calidad de aguas del laboratorio ambiental de la Universidad Distrital (1999) ${ }^{17}$.

El registro de los resultados de los análisis de calidad del agua permitió comparar el comportamiento de las unidades que conforman el experimento y realizar los cálculos, análisis estadísticos y tablas respectivas para dar respuesta a los objetivos e interrogantes planteados.

\section{Fase de operación}

\section{Primera etapa (ajuste experimental y selec- ción de materiales filtrantes alternativos)}

Se partió de los criterios evaluados en el primer prototipo - modelación y selección de las propiedades de los materiales - en lo que respecta a porosidad, densidad, porcentaje de vacíos y superficie de exposición.

En éste caso, se inició con la utilización de materiales considerados residuos de lenta biodegradación (polímetros estables) y su comparación con un material pétreo tradicionalmente utilizado como

17 Cardenas J. Manual de Calidad de Aguas del Laboratorio Ambiental de la Universidad Distrital.1999 
soporte en filtros — gravilla. Los materiales seleccionados fueron:

- Polietileno de baja densidad en PET triturado.

- Espuma de poliuretano (PUR).

- Icopor (poliestireno PS) en perlas.

- Gravilla de diámetro (testigo).

Se tomaron muestras de los materiales seleccionados inicialmente y se les realizaron pruebas para determinar sus propiedades físicas: porosidad o porcentaje de vacíos, área superficial específica $\left(\mathrm{m}^{2} / \mathrm{m}^{3}\right)$, densidad $\mathrm{kg} / \mathrm{m}^{3}$. Así mismo, se tuvieron en cuenta los factores de disponibilidad y costo.

\section{Segunda etapa (adaptación del modelo)}

Los materiales seleccionados fueron adquiridos en zonas comerciales de Bogotá D.C. y se dispusieron, para su medición preliminar, en el Laboratorio de Química y Calidad de Aguas de la Facultad del Medio Ambiente y Recursos Naturales de la Universidad Distrital Francisco José de Caldas. Posteriormente, fueron sometidos al acomodamiento en una batería de filtros experimentales sobre el cuerpo natural contaminado de la quebrada Mi Padre Jesús, ajustando condiciones de operación y diseño del prototipo y manteniendo como referentes los criterios de la etapa de preparación.

\section{Tercera etapa (puesta en operación del prototipo)}

Con el fin de comparar los resultados obtenidos anteriormente de forma conjunta a los de los nuevos materiales, se optó por ubicar — dentro de la continuidad de la investigación preparativa- la prueba experimental en el espacio y en el sistema adaptado en dicha fase del proyecto. En el siguiente diagrama se presentan las adaptaciones y modificaciones de mejoramiento al diseño preliminar:

La alimentación de los módulos se inició con un tratamiento primario conformado por una bocatoma - se construyó con un contenedor plástico con una capacidad para cinco galones - cubierta con una malla plástica de criba mediana en la cual eran retirados los sólidos voluminosos arrastrados por el agua. Del contenedor inicial se condujo el afluente, por medio de una manguera de 2", a un segundo tanque de contención de las mismas características que el primero (cumpliendo la función de trampa de grasas). Ésta trampa se complementó con un filtro elaborado en malla de criba pequeña y ubicado en la manguera de salida con el fin de retener los lodos que hubieran pasado.

FIGURA 2. Sistema primario de tratamiento y montaje del prototipo de la siguiente etapa.

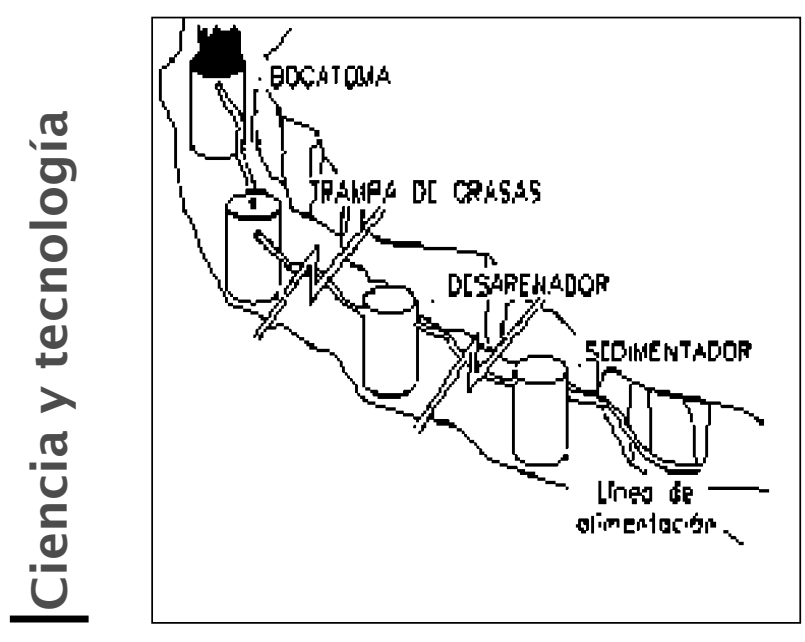

82

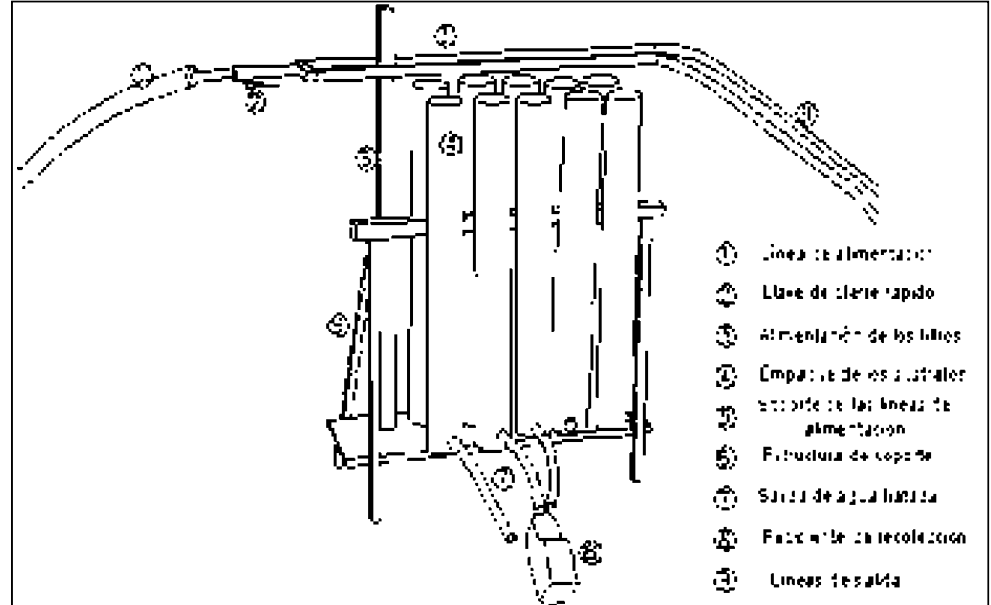

REVISTA CIENTÍFICA / ENERO -DICIEMBRE DE 2010 / No. 12 / BOGOTÁ, D.C. 
Luego se hizo la entrega del efluente al tanque desarenador. Finalmente, el líquido fue conducido a un último contenedor - sedimentador- que estaba complementado por una malla de criba de tamaño más pequeño a la salida. En éste punto finalizó el tratamiento primario y el agua fue conducida por una manguera de 2" hasta la entrada de riego de los módulos.

La alimentación sobre la batería filtro se redujo empleando un tubo de diámetro a $1 / 2$ " mediante una reducción, para así conectarlo con una red de tubería de PVC que distribuía la alimentación del sistema en cada una de las unidades de filtro. Mediante llaves de cierre rápido se reguló el caudal a fin de alcanzar las condiciones requeridas de operación en las unidades filtro. Por su parte, el afluente que no alimentó el filtro fue desviado a dos mangueras que lo condujeron nuevamente a la quebrada Mi Padre Jesús.

\section{Cuarta etapa (muestreo de calidad de aguas)}

Una vez purgada la red — para su estabilizaciónse iniciaron los muestreos de afluentes y efluentes, así como el seguimiento de la operación de las unidades en la siguiente etapa (previa a una condición de contacto del efluente durante un periodo de un mes para propiciar la maduración de la película de biofilm).

Los muestreos del agua del afluente y del agua tratada por cada material se realizaron de la siguiente manera: se tomaron dos litros de agua para la medición de su acidez, alcalinidad, color, conductividad, $\mathrm{DBO}_{5}$, DQO, dureza total, dureza cálcica, dureza magnésica, nitratos, $\mathrm{pH}$, sólidos disueltos, sólidos sedimentables, sólidos suspendidos, sólidos totales fijos, sólidos totales, sólidos volátiles, temperatura y turbidez.

Así mismo, se llevaron a cabo dos muestreos por semana hasta completar diez unidades muéstrales a fin de conservar el modelo establecido en la etapa preliminar del proyecto (en la cual se realizaron igual número de pruebas) y con el objetivo de hacer una comparación bajo condiciones re- lativamente similares de operación de la unidad experimental.

Para disminuir el rango de variación de los resultados se tuvo en cuenta:

- La limpieza completa de los recipientes de recolección.

- El recipiente se enjuagó con la misma agua (objeto del estudio) antes de tomar la muestra.

- Las metodologías empleadas en la determinación de los parámetros fisicoquímicos correspondieron a los procedimientos descritos en el Manual de Laboratorio de Calidad de Aguas, elaborado Hernández $(2003)^{18}$ para la Facultad del Medio Ambiente y Recursos Naturales (UD).

\section{Quinta etapa (análisis de datos y evaluación de resultados)}

En primera instancia se realizó una comparación de los resultados obtenidos en la fase preliminar en relación con los de la fase de operación - tomando como punto de partida la legislación colombiana para agua segura. Con el fin de determinar los índices de calidad se midieron los parámetros de: DBO (Demanda Biológica de Oxígeno), oxígeno disuelto, nitratos, $\mathrm{pH}$, temperatura, sólidos disueltos, fosfatos y turbiedad.

Un segundo análisis se llevó a cabo basándose en la metodología para Índices de Calidad (WQI) implementada en el documento Evaluación de la Calidad del Agua y Diagnóstico Ambiental del Humedal Jaboque ${ }^{19}$

En la última etapa se realizó una matriz de cualificación y cuantificación de algunas características de los materiales evaluados a fin de determinar

18 Actualizado a 2005 por Hernández, Lozano y Guarín, en Notas de Clase. Manejo integral de residuos líquidos Universidad Distrital. FMAy RN

19 CRUZ II Et all. Evaluación de la Calidad del Agua y Diagnóstico Ambiental del Humedal Jaboque. Bogotá D.C. Universidad Distrital Francisco José de Caldas. 2005. Pág. 126 
cuál de ellos, incluyendo la gravilla (como testigo), tuvo el mejor desempeño durante las pruebas.

Los parámetros para dicha la evaluación fueron: desempeño general durante las diferentes pruebas, remoción de contaminantes, comportamiento en el corto plazo (tiempo transcurrido a partir de la puesta en marcha de las pruebas), comportamiento en el mediano plazo (incluyendo las pruebas $\mathrm{V}$ a VI) y, finalmente, comportamiento en el largo plazo (tomando como referencia las pruebas VIII a X).

\section{RESULTADOS}

\section{Fase preliminar (etapa de preparación)}

El uso del primero prototipo con materiales minerales alterados permite establecer un referente del comportamiento de las biopelículas en la remoción de la carga orgánica como elemento para la tratabilidad de las aguas residuales.. De acuerdo con los procesos de evaluación obtenidos - Granja y Yaguara (2004) - para los materiales minerales puestos en filtraje, se establecieron las siguientes características físicas de funcionalidad:

Los resultados enunciados permitieron establecer las condiciones de porosidad eficiente en la conformación de biopelículas estables sobre superficies que brinden relativa uniformidad. En éste caso, la utilización de un material convencional como la gravilla indica una mayor eficiencia en la conformación de biopelículas sin desconocer las potencialidades pertenecientes a los otros dos materiales probados — dado su carácter residual—, aportando, además, elementos orgánicos y minerales que podrían ser incorporados dentro de procesos productivos; el percolador puede ser utilizado nuevamente posterior a su uso dentro del filtrado del agua.

La eficiencia, medida sobre la base a la cantidad total de contaminantes removidos, depende de múltiples factores como la concentración de entrada y el flujo de agua residual — aplicado por unidad de
TABLA 3. Especificaciones de los materiales minerales alterados en la fase preliminar.

\begin{tabular}{|l|c|c|c|}
\hline MEDIO & \%VACíOS & DENSIDAD & ÁREA ESPECÍFICA \\
\hline Gravilla & 44 & $1370 \mathrm{Kg} / \mathrm{m}^{3}$ & $89.4 \mathrm{~m}^{2} / \mathrm{m}^{3}$ \\
\hline Escoria de carbón & 56 & $910 \mathrm{Kg} / \mathrm{m}^{3}$ & $185.1 \mathrm{~m}^{2} / \mathrm{m}^{3}$ \\
\hline Residuo de ladrillo & 64 & $926 \mathrm{Kg} / \mathrm{m}^{3}$ & $114.5 \mathrm{~m}^{2} / \mathrm{m}^{3}$ \\
\hline
\end{tabular}

Fuente: Granja y Yaguara (2004).

área superficial del empaque ${ }^{20}$. Entonces, los modelos que se emplean para predecir la eficiencia tienen un carácter fuertemente empírico y estadístico, lo cual se debe a la complejidad de los fenómenos físicos, químicos y biológicos involucrados en la remoción de los contaminantes. Además de la eficiencia, resulta importante predecir la confiabilidad de la operación.

Debido a su naturaleza propia, la concentración de contaminantes en las aguas residuales fluctúa - por lo general- alrededor de un valor promedio, razón por la cual la concentración de contaminantes a la salida puede sobrepasar, eventualmente, la concentración máxima establecida. Éste efecto se toma en cuenta mediante la confiabilidad; es decir, por medio de la probabilidad de que la concentración de salida sea menor que la concentración máxima establecida.

Los porcentajes de remoción (como parámetro de eficencia) se calcularon con base en la concentración de la DQO (Demanda Química de Oxigeno); éste parámetro permite medir el contenido de materia orgánica — con ayuda de un oxidante fuerte en medio ácido- para determinar el equivalente de oxígeno de la materia orgánica que puede oxidarse. Por tanto, según Metcalf (1998) ${ }^{21}$, los porcentajes de remoción se calculan con base en la DBO o en la DQO:

20 Op. Cit. Winkler (1986) páginas 337-339

21 METCALF \& EDDY, "Ingeniería de Aguas Residuales. Tratamiento, vertido y reutilización”, $3^{a}$ edición, Editorial McGraw-Hill., 1998

REVISTA CIENTÍFICA / ENERO -DICIEMBRE DE 2010 / No. 12 / BOGOTÁ, D.C. 


\author{
$\%$ Remoción $=((\mathrm{CCA}-\mathrm{CCE}) / \mathrm{CCA}) * 100$ \\ Donde;
}

CCA: carga contaminante del afluente.

CCE: carga contaminante del efluente.

En los diversos materiales filtrantes empleados se observa que la DBO y la DQO son parámetros que permiten medir la absorción de compuestos orgánicos en solución y por oxidación bacterial, pues las capas superiores se van llenando paulatinamente de microorganismos en abundancia (los cuales son responsables de la remoción de $\mathrm{DBO}$ y DQO en el agua residual aplicada). Las pruebas de laboratorio evidenciaron una fuerte variabilidad presentada por el efluente en términos de los sedimentos y la alta carga residual a la que es sometida la fuente natural con las descargas pecuarias porcinas (ver anexo 1).

\section{Fase de operación (adaptación del modelo)}

\section{Evaluación de los materiales}

Al igual que en la etapa de preparación inicial, los materiales plásticos propuestos como elementos filtrantes fueron evaluados en sus características físicas tal como se indica en la tabla número 4 .

\section{Muestreos afluentes y efluentes}

Una vez puesto en operación el prototipo de filtración junto con las obras de tratamiento primario del afluente, se procedió al monitoreo de la calidad del agua mediante ensayos desarrollados por el grupo de investigación en el Laboratorio de Química y Calidad de Aguas de la Facultad del Medio Ambiente y Recursos Naturales de la Universidad Distrital Francisco José de Caldas (ver anexo 2). Según el Decreto 1594 del 26 de junio de 1984, en cuanto a usos del agua y residuos líquidos, y específicamente sobre la destinación genérica de las aguas superficiales, subterráneas, marítimas, estuarinas y servidas de las normas de vertimiento - $-\mathrm{y}$ de acuerdo con el Artículo 72-; los vertimientos de un cuerpo de agua deberán cumplir, como mínimo, con las siguientes normas:

- $\quad$ pH 5 a 9 unidades.

- $\quad$ Temperatura $<40^{\circ} \mathrm{C}$.

- Material flotante ausente.

- Grasas y aceites remoción $>80 \%$ en carga.

- Sólidos suspendidos, domésticos o industriales (remoción > 50\% en carga).

- Demanda bioquímica de oxígeno:

\section{TABLA 4. Propiedades físicas de los materiales residuales sintéticos}

\begin{tabular}{|l|c|c|c|}
\hline CARACTERÍSTICAS/ MATERIALES & ESPUMA DE POLIURETANO (PUR) & ICOPOR (POLIESTIRENO PS) EN PERLAS & PET TRITURADO \\
\hline Porosidad o porcentaje de vacíos & $375 \mathrm{~mL}$ & $160 \mathrm{~mL}$ & $315 \mathrm{~mL}$ \\
\hline Área superficial neta & $10,92 \mathrm{~cm}^{2}$ & $0,56 \mathrm{~cm}^{2}$ & $1,65 \mathrm{~cm}^{2}$ \\
\hline Densidad & $17,6 \mathrm{gr}$. & $11,45 \mathrm{gr}$. & $122,5 \mathrm{gr}$. \\
\hline Área superficial neta $\left(\mathrm{m}^{2} / \mathrm{m}^{3}\right)$ & 29,12 & 3,5 & 5,2381 \\
\hline Volumen ocupado por el material & $6,25 \%$ & $60 \%$ & $21,25 \%$ \\
\hline Porosidad o porcentaje de vacíos & $93,75 \%$ & $40 \%$ & $78,75 \%$ \\
\hline Densidad $\mathrm{kg} / \mathrm{m}^{3}$ & 704 & 47,7083 & 1633,33 \\
\hline
\end{tabular}

Fuente: El estudio (2006). 
TABLA 5. Remociones estimadas en diferentes parámetros

\begin{tabular}{|l|c|c|c|c|}
\hline \multirow{2}{*}{ Condición / parámetro } & \multicolumn{4}{|c|}{ REMOCIONES PROMEDIO EFLUENTE } \\
\cline { 2 - 5 } & SÓLIDOS TOTALES & \% DE REMOCIÓN & DQ0 & \% DE REMOCIÓN \\
\hline Afluente & 8830 & & 2.486 .96 & \\
\hline Blanco (gravilla) & 2974 & 66,32 & 1.777 .33 & 28,53 \\
\hline Espuma & 2919 & 66,94 & 851.70 & 65,7 \\
\hline Icopor & 3178 & 64,00 & 2.235 .26 & 10,12 \\
\hline PET & 5891 & 33,28 & 990.67 & 60,12 \\
\hline
\end{tabular}

Fuente: El Estudio (2006).

- Para desechos domésticos (remoción $>30 \%$ en carga).

- Para desechos industriales (remoción $>20 \%$ en carga).

- Sólidos sedimentables $<10 \mathrm{ml} / \mathrm{l}$

Con fundamento en los parámetros de norma y las limitaciones en la determinación de la DBO que se obtuvo del muestreo, se estimó el porcentaje de remoción tal como aparece en la Tabla No. 5 (con base en la DQO que también se emplea para la medición de la materia orgánica presente en agua residuales, tanto industriales como municipales, que contengan compuestos tóxicos para la vida biológica). En diferentes tipos de aguas residuales es posible establecer una relación en donde los valores de la DQO suelan ser mayores con respecto a la DBO; los compuestos se oxidan en mayor proporción por vía química que por vía biológica.

\section{Clasificación de características para la evaluación del funcionamiento de los materiales residuales sintéticos}

La propuesta instrumental se construyó a partir de las indicaciones acerca de la valoración de la calidad de los impactos ambientales (Conesa-Fernandez, 199322) para las características de los cuerpos

22 Conesa Fernandez en Guía metodológica para la evaluación del impacto ambiental 1993. Páginas 190 a 197 superficiales del agua; así mismo, en ella se consideraron tres niveles centrales de comportamiento: el tiempo de los procesos, el comportamiento de los materiales frente a la formación de biofilm y su capacidad de remoción de carga orgánica, y el comportamiento general de todos los parámetros frente a los tratamientos aplicados.

Ésta estructura de valoración apuntó a la construcción de un marco numérico que reflejara el comportamiento de los materiales en su capacidad de remoción como filtros percoladores dentro de la cuantificación de los índices ICA (Îndice de Calidad del Agua) y WQI. A continuación se estipula la escala de calificación y codificación establecida para la evaluación de los parámetros de calidad de agua en cada uno de los materiales:

\section{$\underline{\text { Sigla Material }}$}

$\mathrm{b} \rightarrow \quad$ Blanco (gravilla).

$\mathrm{e} \rightarrow \quad$ Espuma de poliuretano (PUR).

$\mathrm{i} \rightarrow \quad$ Icopor (poliestireno PS).

$\mathrm{p} \rightarrow \quad$ PET (Polyethyleno terephthalato).

Los resultados arrojados por la matriz permiten identificar que el comportamiento de los materiales sintéticos de lenta biodegradación tienen un comportamiento relativamente similar al ofrecido 
TABLA 6. Valoración de condiciones de estabilidad y rendimiento de los materiales filtrantes sintéticos

\begin{tabular}{|l|c|l|l|l|l|l|l|l|l|l|l|}
\hline \multicolumn{2}{|l|}{ COMP. GRAL. } & \multicolumn{2}{l|}{ REMOCIÓN } & \multicolumn{2}{l|}{ COMP. CORTO PLAZO } & \multicolumn{2}{l|}{ COMP. MEDIANO PLAZO } & \multicolumn{2}{l|}{ COMP. LARGO PLAZO } \\
\hline ALTO & 4 & CRECIENTE & 3 & ALTO & 3 & ALTO & 3 & ALTO & 3 \\
\hline MEDIO & 3 & ESTABLE & 2 & MEDIO & 2 & MEDIO & 2 & MEDIO & 2 \\
\hline REGULAR & 2 & DECRECIENTE & 1 & BAJO & 1 & BAJO & 1 & BAJO & 1 \\
\hline BAJO & 1 & \multicolumn{7}{|l|l|}{}
\end{tabular}

TABLA 7. Clasificación de características para la evaluación del funcionamiento de los materiales residuales sintéticos

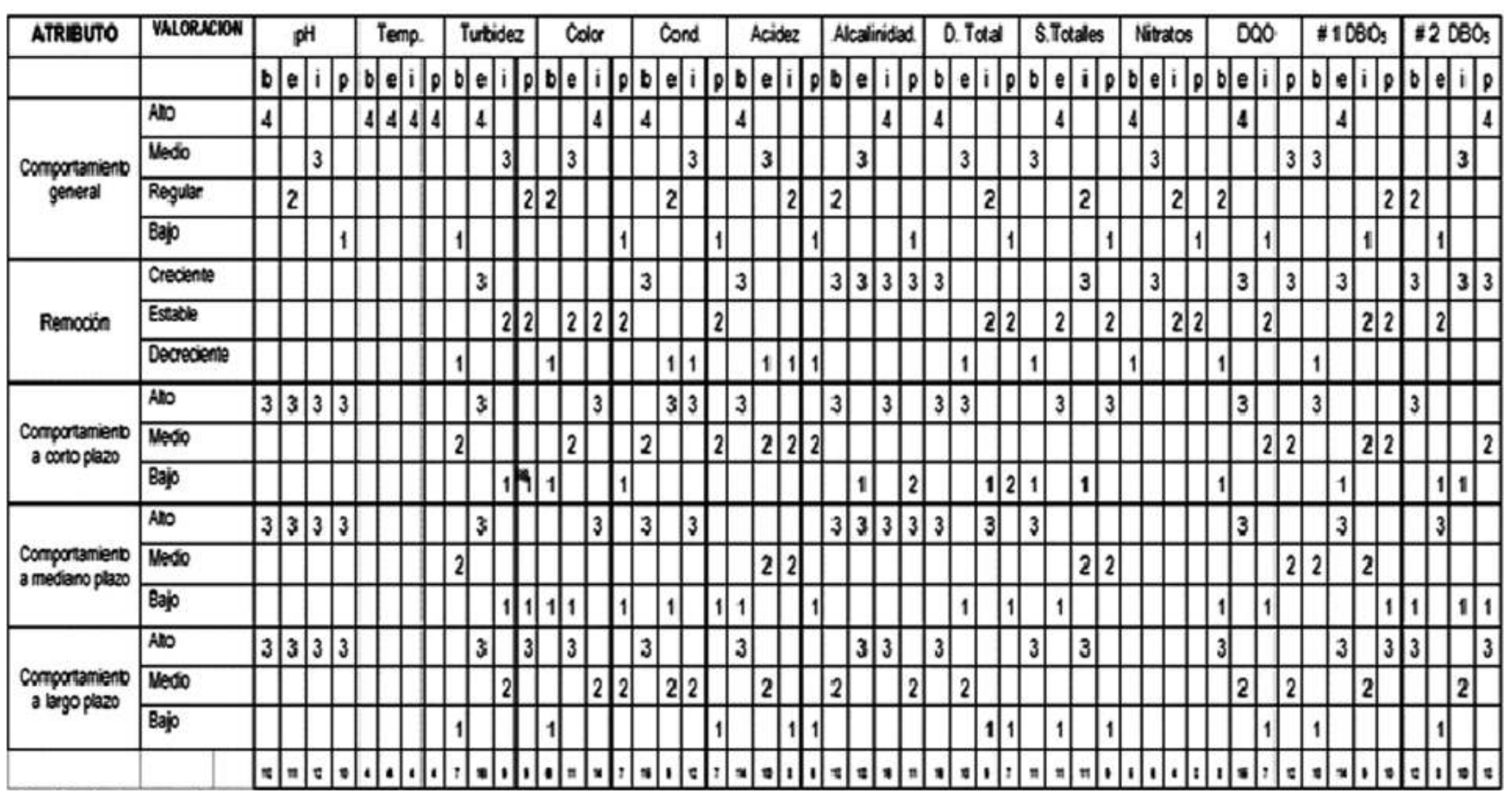

por uno tradicional como la gravilla; que alcanza una valoración de 134pts, siendo levemente superada por la espuma de poliuretano con 138pts y, en una menor calificación, el icopor (125pts) y el PET (108pts).

\section{Índices de calidad (WQI)}

Para éste estudio se tomó como referente de aplicación la metodología para Îndices de Calidad (WQI) implementada en el proyecto Evaluación de la Calidad del Agua y Diagnóstico Ambiental del Humedal
Jaboque (2005) ${ }^{23}$; así como referencias en las herramientas de Información Ambiental en Desarrollo y Prue$b a^{24}$ utilizadas en la estimación del Índice de Biodiversidad Canadiense (CBI); proporcionan las instancias decisorias mediante un mensaje claro y fácilmente comprensible sobre el estado de la calidad de un cuerpo de agua - incluyendo parámetros físicos, químicos y biológicos — que, por sí mismos, no su-

\section{Op.Cit. Cruz, I. Et. Al. 2005. Pág. 126}

24 http://www.conama.cl/chilecanada/1288/article-29760. html. Artículo 2(1) (a) - Informes sobre el Estado del Medio Ambiente. 
ministran el diagnóstico adecuado. El proceso para el desarrollo del Índice de Calidad del Agua (ICA) se desarrolló en las siguientes etapas:

I. La identificación de factores claves (parámetros biológicos, químicos o físicos) que pueden emplearse como indicadores de la calidad del agua - basados en el criterio profesional colectivo de personas con conocimientos referentes al medio acuático o al foco de contaminación.

II. Asignación de los pesos relativos o peso de importancia del parámetro (wi) correspondientes a los factores de contaminación en aguas: en ésta fase se corre el riesgo de introducir cierto grado de subjetividad en la evaluación; no obstante, por otro lado sugiere la importancia de una asignación racional y unificada de dichos pesos - de acuerdo al uso del agua- y la trascendencia de los parámetros en relación al riesgo que implica el aumento o disminución de su concentración.

El ICA adopta, para condiciones óptimas, un valor máximo determinado de 100 , el cual disminuye - con el aumento de la contaminación- el curso de agua en estudio. Luego del cálculo, el índice de calidad de agua de tipo "general" se clasifica con base en la tabla No. 8 .

El primer paso es calcular el factor. Para ello debe otorgársele un valor a cada parámetro de acuerdo

\section{TABLA 8. Clasificación del ICA propuesto por Brown}

\begin{tabular}{|l|c|c|}
\hline CALIDAD DE AGUA & COLOR & VALOR \\
\hline Excelente & & 91 a 100. \\
\hline Buena & & 71 a 90. \\
\hline Regular & & 51 a 70. \\
\hline Mala & & 26 a 50. \\
\hline Pésima & & 0 a 25. \\
\hline
\end{tabular}

Fuente: José Lobos, Evaluación de los Contaminantes del Embalse del Cerrón Grande Paes (2002). a la prioridad u objetivo del análisis y luego realizar una sumatoria total (el resultado de ésta debe ser 1). Por su parte, el segundo paso es hallar los valores de $\mathrm{Q}$ en cada uno de los parámetros de acuerdo a los resultados obtenidos. Su cálculo se establece a partir de las gráficas en donde se registran los valores, en el eje $\mathrm{X}$ se localizan los resultados por parámetro y en el eje $\mathrm{Y}$ el valor de Q, (intercepto de curva de parámetros y eje $\mathrm{Y}$ ).

Luego de tener el valor de Q hay que hallar WQI (esto se hace multiplicando el valor del factor por el de Q) y, finalmente, se realiza la sumatoria de los valores arrojados después de haber hallado el WQI de todos los parámetros. Éste valor determina el grado de la calidad del agua para el cuerpo de agua. Entre tanto, como se explicaba anteriormente, WQI utiliza rangos de 0 a 100 para clasificar la calidad de los cuerpos de agua — siendo 100 la mejor valoración.

\section{TABLA 9. Rangos de calidad WQI.}

\begin{tabular}{|l|c|}
\hline CALIDAD & RANGO \\
\hline Excelente & $91-100$. \\
\hline Buena & $71-90$. \\
\hline Media & $51-70$ \\
\hline Admisible & $26-50$. \\
\hline \multicolumn{2}{|l|}{ Inadmisible } \\
Fuente: Modificado de Cruz (2004), Evaluación de la Calidad del \\
$\begin{array}{l}\text { Agua y Diagnóstico Ambiental del Humedal Jabo- } \\
\text { que. }\end{array}$
\end{tabular}

Un último análisis fue la realización de una matriz de clasificación de algunas características de los materiales evaluados. Para determinar qué material —incluyendo el blanco (gravilla) — tuvo el mejor desempeño durante las pruebas, se procedió a establecer unos parámetros de comparación del comportamiento de los materiales: desempeño general durante las pruebas, remoción de contaminantes, comportamiento en el corto plazo (tiempo transcurrido desde la puesta en marcha de las pruebas hasta la IV), comportamiento en el mediano plazo

REVISTA CIENTÍFICA / ENERO -DICIEMBRE DE 2010 / No. 12 / BOGOTÁ, D.C. 
(incluyendo las pruebas V a VII) y, finalmente, el comportamiento en el largo plazo tomando como referencia las pruebas VIII a X.

Una vez definidos los patrones a analizar, se procedió a darles un valor dentro de una escala de eficiencia — el más alto fue asignado al material que marcó el mejor desempeño y el más bajo al que estuvo más alejado de los parámetros legales. En seguida, se realizó una sumatoria de éstos valores, obteniendo un resultado total para cada material y determinando como el de mejor desempeño al que obtuvo el puntaje mayor. De igual manera, se asignó una escala de colores para cada valor — reflejando eso en la matriz —; sirvió para determinar el porcentaje de rasgos positivos y negativos obtenidos en los diferentes materiales.

\section{TABLA 10. Calificación de calidad del agua (WQI) para los materiales filtrantes}

\begin{tabular}{|l|l|l|}
\hline ELEMENTO & WQI & CALIDAD DEL AGUA \\
\hline Afluente & 19,5 & Inadmisible \\
\hline Blanco (gravilla) & 14,2 & Inadmisible \\
\hline Espuma de poliuretano (PUR) & 25,2 & Inadmisible \\
\hline Icopor (poliestireno PS) & 15,5 & Inadmisible \\
\hline PET & 13,5 & Inadmisible \\
\hline WQI con la DBO en mayor dilución. $^{\mid}$ \\
\hline ELEMENTO & WQI & CALIDAD DEL AGUA \\
\hline Afluente & 21,1 & Inadmisible \\
\hline Blanco (gravilla) & 17,4 & Inadmisible \\
\hline Espuma de poliuretano (PUR) & 26,8 & Admisible \\
\hline Icopor (poliestireno PS) & 18,7 & Inadmisible \\
\hline PET & 17,1 & Inadmisible \\
\hline
\end{tabular}

Fuente: El Estudio (2006).

\section{Evaluación de la eficiencia de los materiales.}

Los resultados se obtuvieron calificando de 1 (más baja) a 4 (más alta). Por su parte, los parámetros que obtuvieron la mejor calificación fueron los que estuvieron más cerca a los valores establecidos por la legislación colombiana — si estaban distantes de éstos, se calificaban entre ellos. Dependiendo del objetivo del parámetro, el que hubiera hecho un mejor trabajo obtenía la mejor calificación - y el peor la más baja.

Para calcular el Índice de Brown se puede utilizar una suma lineal ponderada de los subíndices (ICAa) —o una función ponderada multiplicativa (ICAm) - de acuerdo con la asignación establecida en la página 23. Los resultados de la valoración numérica se presentan en la Tabla No. 11.

\section{TABLA 11. Calificación del comportamiento de los materiales como sustento para el biofilm de acuerdo a los promedios obtenidos en las pruebas.}

\begin{tabular}{|c|c|c|c|c|}
\hline Parámetro/ material & 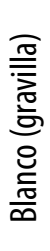 & 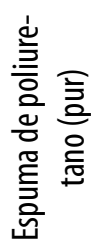 & 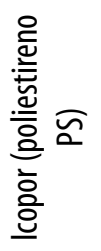 & PET \\
\hline $\mathrm{pH}$ & 4 & 4 & 4 & 4 \\
\hline Temperatura & 4 & 4 & 4 & 4 \\
\hline Turbidez & 1 & 4 & 3 & 2 \\
\hline Color & 2 & 3 & 4 & 1 \\
\hline Conductividad & 4 & 2 & 3 & 1 \\
\hline Acidez & 4 & 3 & 2 & 1 \\
\hline Alcalinidad & 2 & 3 & 4 & 1 \\
\hline Dureza total & 4 & 3 & 2 & 1 \\
\hline Sólidos totales & 3 & 4 & 2 & 1 \\
\hline DQO & 2 & 4 & 1 & 3 \\
\hline Nitratos & 4 & 3 & 2 & 1 \\
\hline DBO 1 dilución & 1 & 1 & 1 & 1 \\
\hline DBO 2 dilución & 1 & 1 & 1 & 1 \\
\hline 0xígeno disuelto inicial & 1 & 2 & 3 & 4 \\
\hline \multirow[t]{2}{*}{ Oxígeno disuelto final } & 1 & 2 & 3 & 4 \\
\hline & 38 & 43 & 39 & 30 \\
\hline
\end{tabular}

Fuente: El Estudio (2006). 


\section{ANÁLISIS DE RESULTADOS}

\section{Análisis del afluente y de los efluentes}

Los procesos de evaluación en laboratorio, así como las evidencias recogidas en campo, evidencian graves problemas de contaminación en la quebrada Mi Padre Jesús; cuyo comportamiento de calidad hídrica la hace comparable a un efluente de aguas residuales con excesiva carga orgánica. Con base en los resultados de éste estudio, y considerando el Índice de Calidad del Agua (ICA), el cuerpo de agua analizado se encuentra deteriorado en referencia a los parámetros considerados como mínimos para su funcionalidad como corriente natural superficial.

Los criterios de calidad utilizados para la evaluación del drenaje se compararon según el Decreto 475 de 1998, el cual determina las normas técnicas de calidad del agua potable y segura; Artículo 35, que hace referencia a las normas organolépticas, físicas, químicas y microbiológicas de la calidad del agua segura; Artículo 36, basado en criterios de calidad organoléptica y física del agua; y Artículo 37, que trata acerca de los criterios de calidad química del agua segura. Considerando las condiciones de calidad de agua encontradas, así como su fuente de origen, a continuación se hace referencia breve a los parámetros empleados para el análisis.

Los resultados de éstos ensayos guardan ciertas relaciones entre sí pero tienen significados diferentes. La DBO5 se mide como mg/lt o ppm de O2 consumidas durante un período de 5 días a una temperatura de $20^{\circ} \mathrm{C}$ en la oscuridad. Entre tanto, la DBO es la medida utilizada por excelencia en las agencias reguladoras en todo el mundo para calcular el impacto de la contaminación causada por las aguas residuales. A título meramente indicativo se pueden establecer los siguientes parámetros:

$\begin{array}{lcc}\text { Estado } & \text { DB05; } & \mathrm{mg} / \mathrm{lt} \\ \text { Agua pura } & 0-20 & \mathrm{mg} / \mathrm{lt} \\ \text { Agua levemente contaminada } & 20-100 & \mathrm{mg} / \mathrm{lt} \\ \text { Agua medianamente contaminada } & 100-500 & \mathrm{mg} / \mathrm{lt} \\ \text { Agua muy contaminada } & 500-3000 & \mathrm{mg} / \mathrm{lt} \\ \text { Agua extremadamente contaminada } & 3000-15000 & \mathrm{mg} / \mathrm{lt}\end{array}$

\section{Parámetros experimentales evaluados:}

Alcalinidad: el comportamiento de los materiales usados (en la fase preliminar) estuvo por encima de los parámetros establecidos por la legislación colombiana determinada para agua segura (Decreto 475 de 1998 expedido por el Ministerio de Salud) —de hecho, sólo hasta el No. 8 se ubicó dentro del mismo. También fue notorio que, debido al comportamiento aleatorio de los resultados, no puedo llevarse a cabo una lectura que indicara si hubo tendencia al aumento o al descenso.

En la fase operativa, desde el principio del muestreo, se registraron valores por debajo del límite señalado por la legislación - éste comportamiento fue constante durante la realización de las pruebas. A partir de la segunda muestra empezó a evidenciarse una tendencia al descenso de éste parámetro, la cual se conservó hasta el final de las pruebas (exceptuando el octavo muestreo).

\section{GRÁFICA 1. Comportamiento de la alcalinidad} en la fase preliminar.

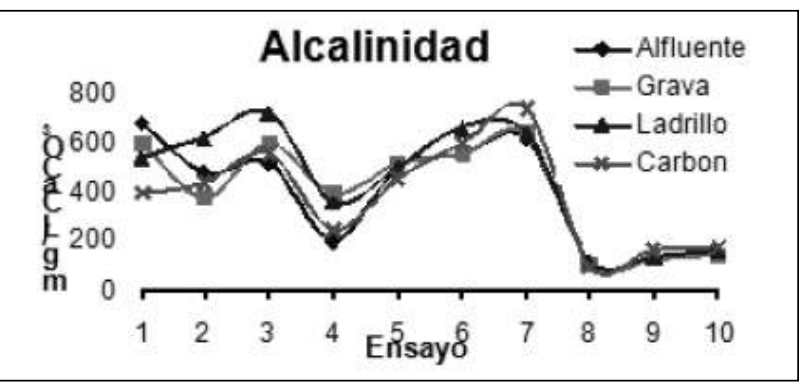

Fuente: Adaptado de Granja y Yaguara (2004).

\section{GRÁFICA 2. Comportamiento de la alcalinidad en la fase operativa}

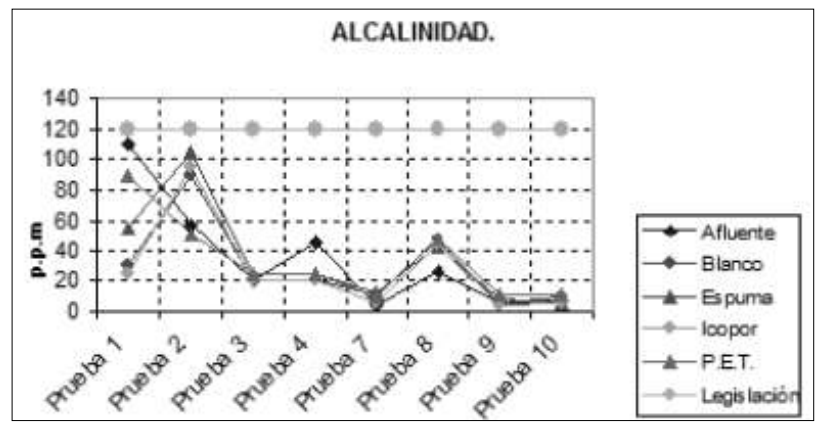

Fuente: Los Autores (2006).

REVISTA CIENTÍFICA / ENERO -DICIEMBRE DE 2010 / No. 12 / BOGOTÁ, D.C. 
Sólidos sedimentables: después de dos meses de funcionamiento (en la fase preliminar) sin evaluación en laboratorio, los sólidos presentes en el agua residual fueron depositados en el medio — situación que perjudicó la eficiencia del filtro. En consecuencia, fue implementada una trampa de grasas y un sedimentador como protecciones para el filtro percolador; por su parte, éstas unidades no generaron resultados importantes sino a partir del ensayo número 4 , cuando se realizó un cuidadoso lavado del material procurando arrastrar la menor cantidad de biofilm (retirando el sedimento acumulado y generando una renovación del mismo).

En la fase operacional del proyecto, los materiales utilizados permitieron la acumulación de agua en los filtros, hecho que ayudó a aumentar la tasa de remoción. Además, los materiales de prueba presentaron mejores características para remover materia orgánica frente a los utilizados en la fase preliminar. Lo anterior debido al poco espacio intersticial brindado por los materiales -el cual se rellenó fácilmente con biofilm-, facilitándose una disminución en la velocidad del filtrado (permitiendo la sedimentación por gravedad).

Sólidos totales: al confrontar la eficiencia de los materiales evaluados tanto en la fase operativa como en la fase preliminar, se determinó que los materiales usados en las dos etapas tenían un comportamiento similar; fueron bastante irregulares $y$ no presentaron tendencias a la disminución de los sólidos.

Cabe recordar que en los procesos biológicos siempre se produce un remanente y, en éste caso, estuvo añadido a los sólidos procedentes del agua a tratar durante el desarrollo de la siguiente etapa - causando un aumento del registro a la salida de los filtros. A pesar que estos valores de aumento y disminución fueron oscilantes, la tendencia constante fue a mantenerse por encima de los valores del afluente.

En cuanto al valor máximo que indica la legislación para agua segura (Decreto 475 de 1998 expedido por el Ministerio de Salud), que es menos de

\section{GRÁFICA 3. Comportamiento de los sólidos totales} en la fase preliminar.

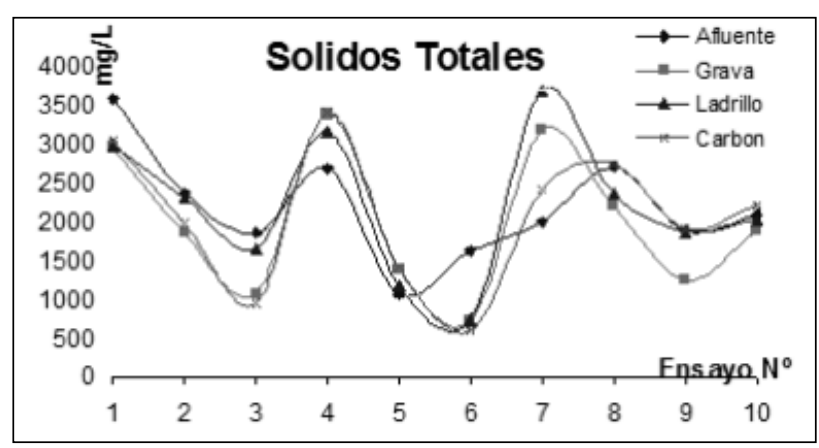

Fuente: el estudio (2006).

\section{GRÁFICA 4. Comportamiento de los sólidos totales en la fase operativa}

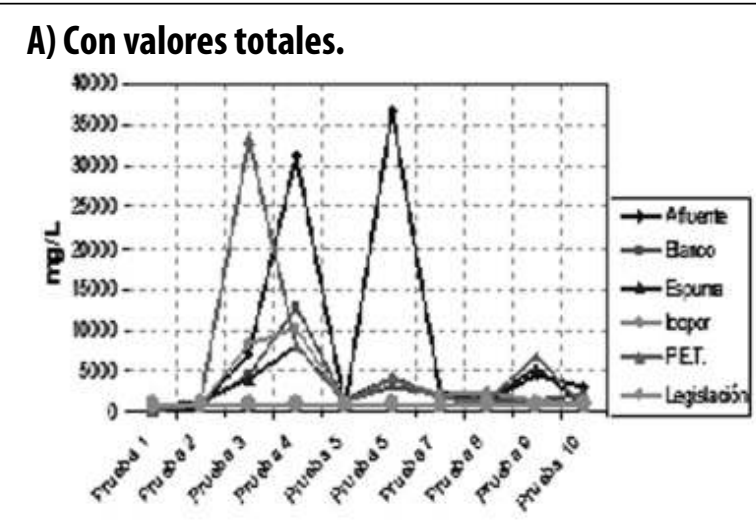

\section{B) Sin los valores más altos.}

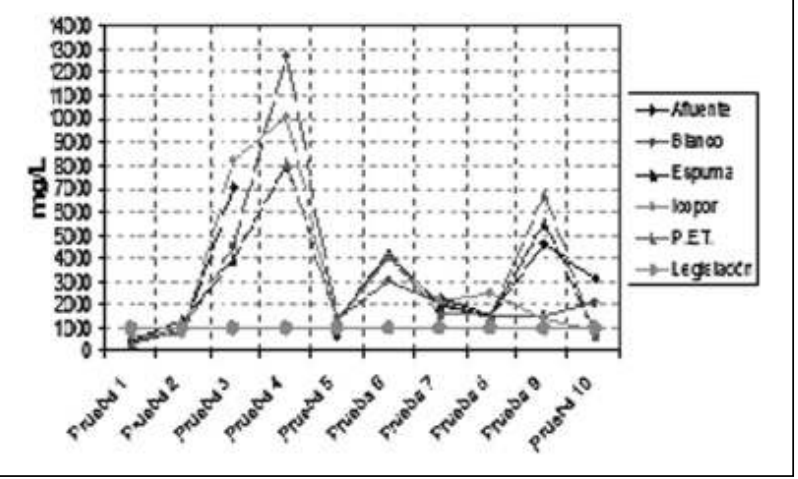

Fuente: el estudio (2006).

1000 p.p.m., ninguno de los materiales evaluados en las dos etapas cumplió con el objetivo.

En la gráfica 4a se representaron todos los valores de los sólidos totales; y en la gráfica $4 \mathrm{~B}$, los obteni- 
dos en el laboratorio — sin los datos más altos con fin de observar la tendencia de los valores dentro de una escala más baja.

DQO: éste parámetro es uno de los más importantes ya que permite evaluar parte de la eficiencia del

\section{GRÁFICA 5. Comportamiento de la DQO en la fase preliminar.}

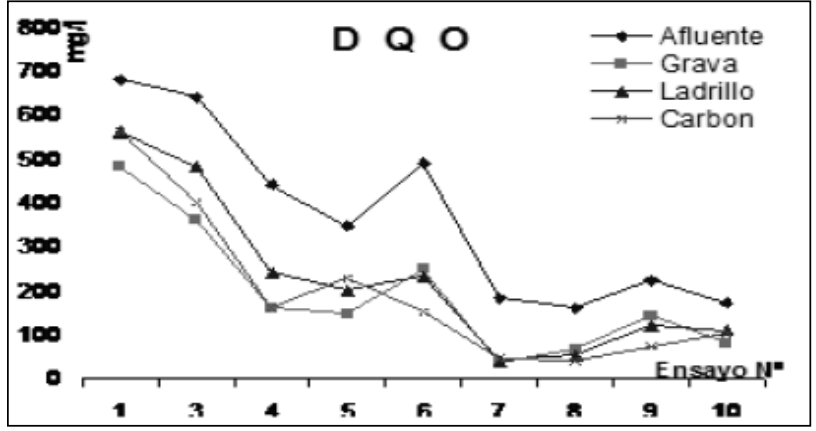

Fuente: el estudio (2006).

\section{GRÁFICA 6. Comportamiento de la DQO} en la fase operativa

\section{A) Con valores totales.}

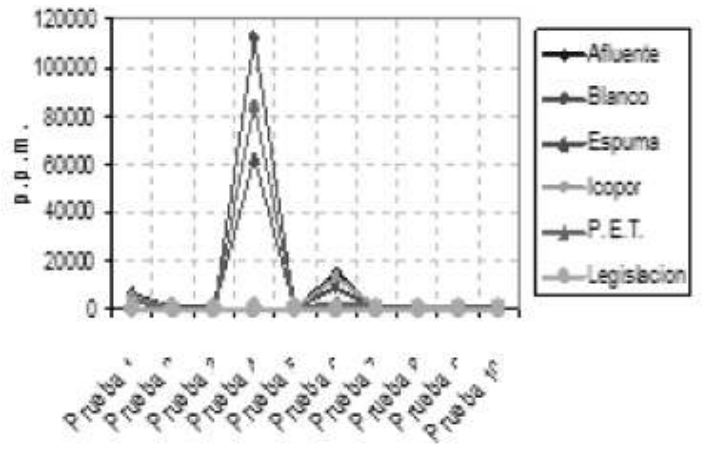

B) Sin los valores más altos.

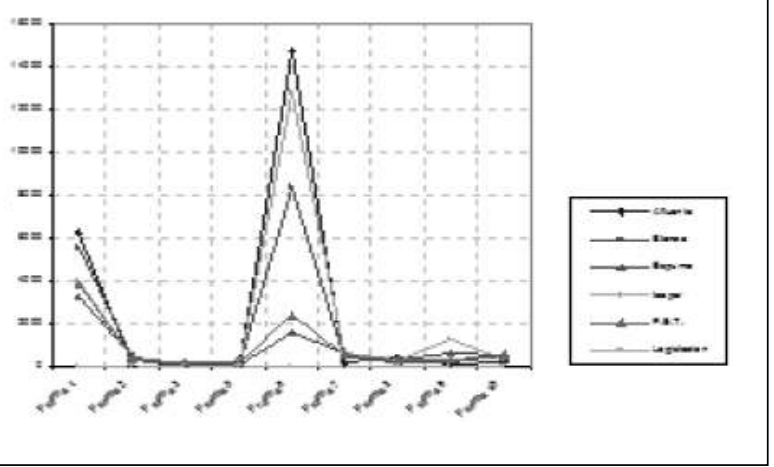

Fuente: el estudio (2006). tratamiento. En la fase preliminar del proyecto se pudo apreciar una tendencia al descenso $y$, aunque se presentó un máximo en la prueba 6 , la tendencia fue a disminuir. Al comparar estos resultados con los obtenidos en la siguiente fase, se puede afirmar que éste tratamiento no fue tan efectivo; nunca estuvo cerca de las 30 p.p.m que autoriza la legislación colombiana. Cabe recordar que en la fase preliminar no se presentaron descargas tan altas de materia orgánica al afluente, pues se obtuvieron resultados máximos de 680 p.p.m. vs. 84000 p.p.m. (en las pruebas 4 y 6 , y en días en los que la calidad de agua proveniente del afluente fue más compleja en términos de la carga). En consecuencia, la meta de las 30 p.p.m. es muy difícil de alcanzar debido a la contaminación del agua de la quebrada.

En la gráfica 6a se representan los valores obtenidos al comparar los materiales; mientras que en la $6 \mathrm{~b}$ se realiza un acercamiento para poder observar el máximo alcanzado en la prueba No.6

En la fase preliminar algunos parámetros no fueron considerados para fines investigativos. Posteriormente, en la fase operativa, se complementaron parámetros de calidad que permitieran hacer un análisis más integral con respecto a la primera fase. A continuación se muestran los análisis de los parámetros adicionales medidos en la fase operativa.

Dureza total: se observó que los resultados arrojados por los materiales estuvieron, la mayor parte del tiempo, dentro de los límites establecidos por la

\section{GRÁFICA 7. Comportamiento de la dureza total fase operativa.}

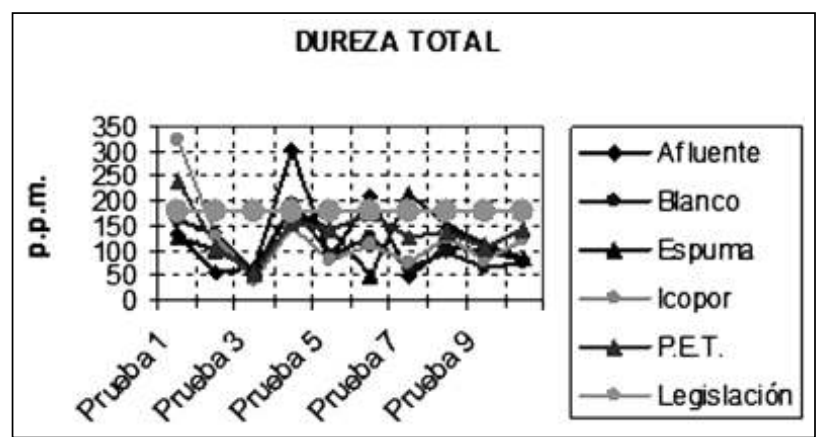

Fuente: los Autores (2005).

REVISTA CIENTÍFICA / ENERO -DICIEMBRE DE 2010 / No. 12 / BOGOTÁ, D.C. 
legislación para agua segura (Decreto 475 de 1998 expedido por el Ministerio de Salud); es decir, en un valor de 180 p.p.m. Sin embargo, no puede suponerse que los materiales trabajaron bien en la disminución de la dureza; los datos se presentaron aleatoriamente sin exhibir una tendencia a disminuir (hubiera sido el comportamiento esperado).

DBO $_{5}:$ no fue comparado con la etapa preliminar porque en ésta no se realizó la medición del parámetro (aunque, junto con la DQO, es un indicador muy importante para determinar la eficiencia de los tratamientos biológicos). En la gráfica 8 a se representan los resultados obtenidos por la muestra; y en la gráfica 8 b, se registran los resultados de la contra muestra.

El comportamiento en ésta prueba fue bastante variado, pues nunca se obtuvo el nivel indicado por la legislación colombiana (menos de 20 p.p.m.). Una de las principales causas pudo haber sido la

\section{GRÁFICA 8. Comportamiento de la DQO en la fase operativa}

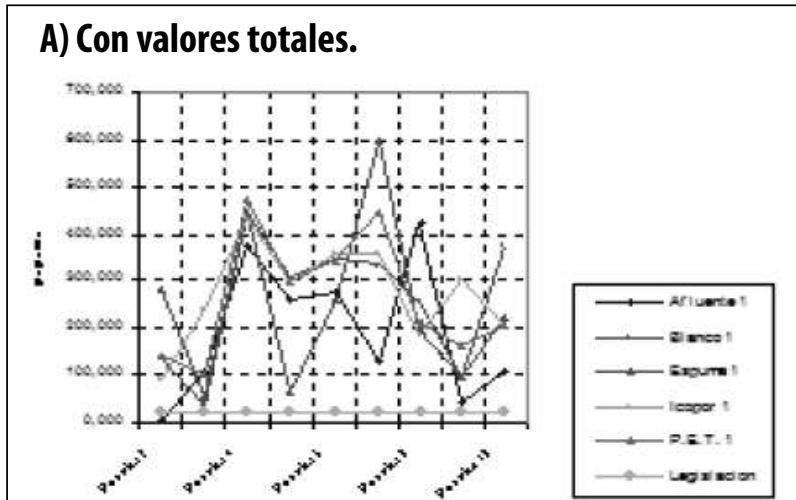

B) Sin los valores más altos.

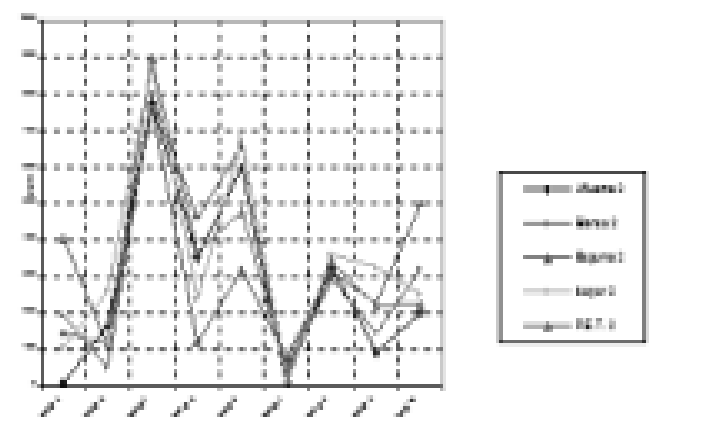

Fuente: el estudio (2006). decisión de no limpiar los filtros para observar el comportamiento de la acción de éstos frente al crecimiento del biofilm; su expansión aportó gran cantidad de materia orgánica — desplazada por el movimiento del agua- $\mathrm{y}$ afectó las mediciones.

\section{Análisis de los materiales}

Aunque la gravilla no posee el mayor índice de porosidad (44\% de vacíos), su eficiencia en la remoción de materia orgánica puede ser más alta en relación a la escoria de carbón; éste presentó, en la mayoría de los ensayos, un valor cercano o ligeramente superior al de la gravilla. Lo anterior puede atribuirse a la uniformidad del medio, la cual genera una distribución más compacta del material en el lecho y una formación de biofilm más uniforme - aumenta el tiempo de contacto con el agua residual. Entre tanto, los otros materiales analizados en la fase preliminar presentaron porcentajes mayores de vacíos.

En la fase operativa, dos de los materiales utilizados exhibieron mejores características de porosidad. Por ejemplo, pudo determinarse que la espuma de poliuretano (PUR) es el material más apto para ésta función ya que posee un $93,75 \%$ de vacíos en comparación con el PET; una porosidad de 78,75 $\%$ en contraste con el icopor (poliestireno PS); y su valor es menor en un $40 \%$ comparado con el de la gravilla. Así mismo, la espuma presentó mayor capacidad de adhesión de células $y$, por ende, un mejor medio para la formación del biofilm.

En la fase preliminar se observó que el carbón, dada su forma irregular, provee una gran área de contacto entre el líquido y la lama microbiana. En consecuencia, se concluyó que la eficiencia de remoción de materia orgánica del residuo del carbón se debe a ésta propiedad y no a la porosidad. Así mismo, el carbón influyó en los otros materiales (aunque no en la misma proporción que en el residuo del carbón).

Para la fase operativa se determinó que al cubrir total y uniformemente el sustrato por el biofilm, se 
efectúa un mejor tratamiento ya que el agua permanece durante más tiempo en contacto con todo el biofilm y, de ésta manera, se adquiere una mayor eficiencia por cada material. Así pues, el material ideal fue el icopor - poliestireno PS - en perlas; presentó la menor área superficial $3.5 \mathrm{~m}^{2} / \mathrm{m}^{3}$ (como el PET; sin embargo, éste es el material más pesado de los tres y demanda mayores inversiones en estructura para contenerlo).

Por su parte, la espuma de poliuretano (PUR) ocupó un gran espacio superficial y ocasionó que el crecimiento de la capa de biofilm se adhiriera de forma irregular. Incluso, con el tiempo, sus características superficiales se modificaron por las presiones; perdieron la forma y disminuyeron el porcentaje de vacíos, hecho que supuso su continuo reemplazamiento.

Para la formación de biofilm se necesita que el material del sustrato - por medio de su porosidadpermita una adhesión primaria rápida; ésta se da en segundos o en minutos. En el sustrato virgen es donde se agrupan las células iniciales y si el material del sustrato no les brinda una adhesión ideal, no ocurrirá una buena acumulación de células que permitan la adhesión secundaria para iniciar el crecimiento del biofilm.

Debido a la porosidad presente en la espuma de poliuretano (PUR), se determinó que es el mejor material para ésta función: posee un $93,75 \%$ de vacíos en comparación con el PET (78,75\%) y el icopor (40\%). Esto demuestra que la espuma presentó mayor ca- pacidad de adhesión de células y, por ende, un mejor medio para la formación del biofilm.

Desde el punto de vista económico, el material idóneo es el PET ya que se consigue reciclado, con mayor facilidad y a bajo costo. Por el contrario, la espuma de poliuretano es difícil de adquirir; después de un periodo de uso pierde sus cualidades mecánicas $\mathrm{y}$, además, su proceso de desinfección es muy dispendioso. En el caso del icopor, su presentación en forma de perlas representa una inversión muy alta.

\section{Análisis del índice de calidad (WQI)}

En la matriz de la tabla No. 11 para la fase operativa se aprecia el resultado de la asignación de un color específico a cada valor. Lo anterior permite visualizar el comportamiento de los materiales y tener una imagen cercana del desempeño general de los mismos durante las pruebas. Se destaca, además, que los resultados positivos (en azul) son abundantes y los negativos (en rojo) son mayoritarios.

Luego de sumar los valores obtenidos para cada material se obtuvo una calificación que permitió compararlos. Basado en ello, el mejor comportamiento de las pruebas fue el presentado por la espuma de poliuretano, seguido por el blanco (gravilla), el icopor y el PET. Éstos datos confirman lo observado durante las pruebas y otros análisis realizados.

En las siguientes tablas se expone la determinación de características por material para abordar,

\section{TABLA 12. Matriz de valoración de ICA de los materiales en la fase operativa}

\begin{tabular}{|c|c|c|c|c|c|c|c|}
\hline \multicolumn{2}{|l|}{ REMOCIÓN } & \multicolumn{2}{|c|}{ COMP. GRAL. } & \multicolumn{2}{|c|}{ COMP. CORTO PLAZO } & \multicolumn{2}{|c|}{ COMP. MEDIANO PLAZO } \\
\hline CRECIENTE & 3 & ALTO & 4 & ALTO & 3 & ALTO & 3 \\
\hline ESTABLE & 2 & MEDIO & 3 & MEDIO & 2 & MEDIO & 2 \\
\hline DECRECIENTE & 1 & REGULAR & 2 & BAJO & 1 & BAJO & 1 \\
\hline & & BAJO & 1 & & & & \\
\hline
\end{tabular}

Fuente: el Estudio (2006). 
TABLA 13. Valoración de las características

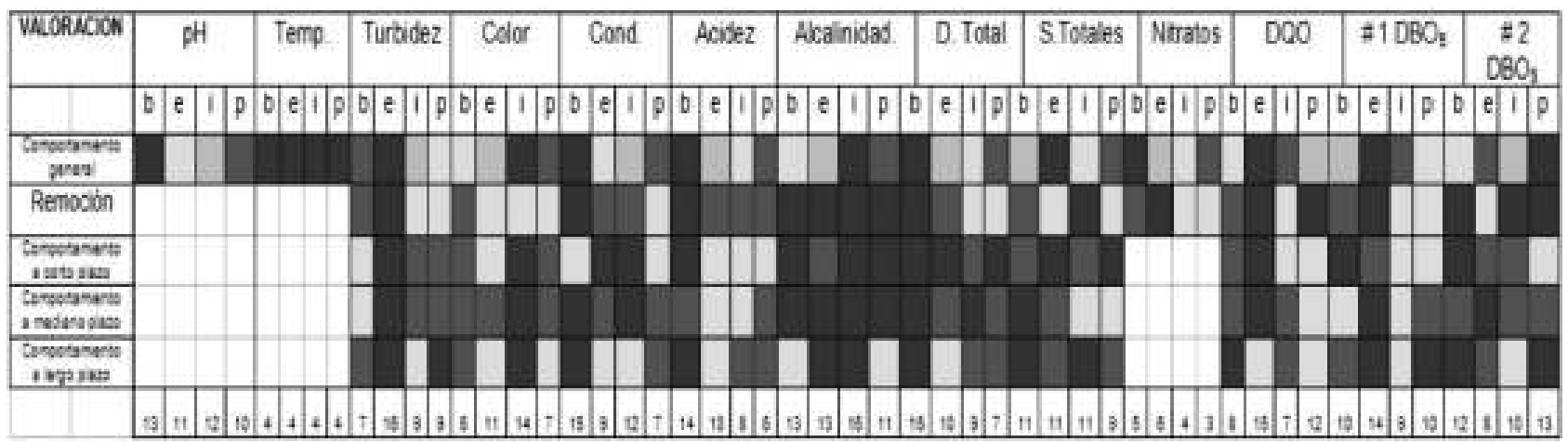

\section{TABLA 14. Valor alcanzado por cada material}

\begin{tabular}{|l|c|}
\hline MATERIAL & CALIFICACIÓN \\
\hline Blanco & 134 \\
\hline Espuma de Poliuretano (PUR) & 138 \\
\hline Icopor (Poliestireno PS) & 125 \\
\hline PET & 108 \\
\hline
\end{tabular}

Fuente: el Estudio (2006).

finalmente, la identificación de las propiedades deseables e indeseables. De ésta manera podrán entenderse las razones por las cuales algunos se comportaron mejor que otros, así como sus aciertos y fallas.

\section{TABLA 15. Matriz de totalización de características del blanco.}

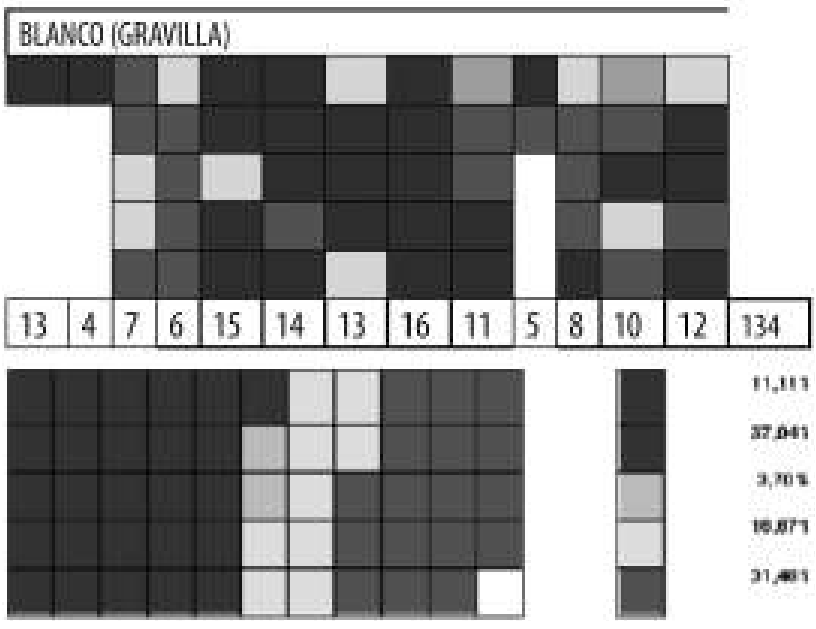

Fuente: el Estudio (2006).

REVISTA CIENTÍFICA / ENERO -DICIEMBRE DE 2010 / No. 12 / BOGOTÁ, D.C.
Los tonos azules representan los puntajes deseables. La proporción de éstos es alta pero, así mismo, lo es la proporción de puntajes malos; hecho que afecta el promedio de eficiencia del material. El puntaje bueno es el 51,85\%; el aceptable, representado por el color amarillo, es igual a 16,67\%; y el inaceptable es el $31,48 \%$. De 175 pts posibles se obtuvieron 134pts, lo que representa una eficiencia comparativa del 76,57\%.

\section{TABLA 16. Matriz de totalización de características de la espuma de poliuretano (PUR).}

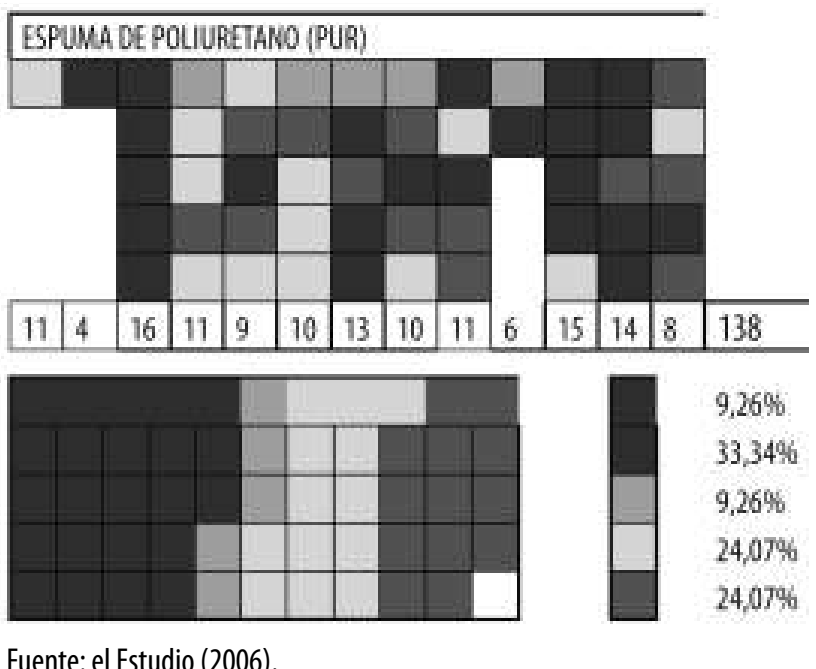

Fuente: el Estudio (2006).

En este caso el puntaje bueno representa el 51,86\%, mientras que el aceptable es mayor $(24,07 \%)$ y el inaceptable se redujo a $24,07 \%$. De 175 pts posibles se obtuvieron 138pts, lo que significa un porcentaje de eficiencia comparativa del $78,86 \%$. 
TABLA 17. Matriz de totalización de características del icopor (poliestireno PS)
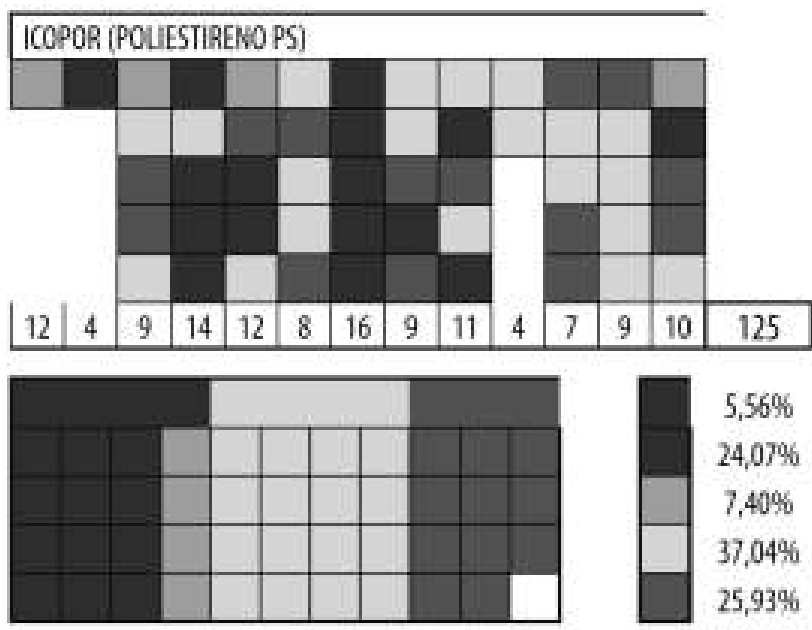

Fuente: el Estudio (2006).

El puntaje obtenido en el rango alto fue del $37,03 \%$, el aceptable representó el $37.04 \%$; mientras que el inaceptable fue igual al 25,93\%. De los 175 pts se obtuvieron 125pts.; es decir, una eficiencia del $71.42 \%$.

\section{TABLA 18. Matriz de totalización de características del PET}

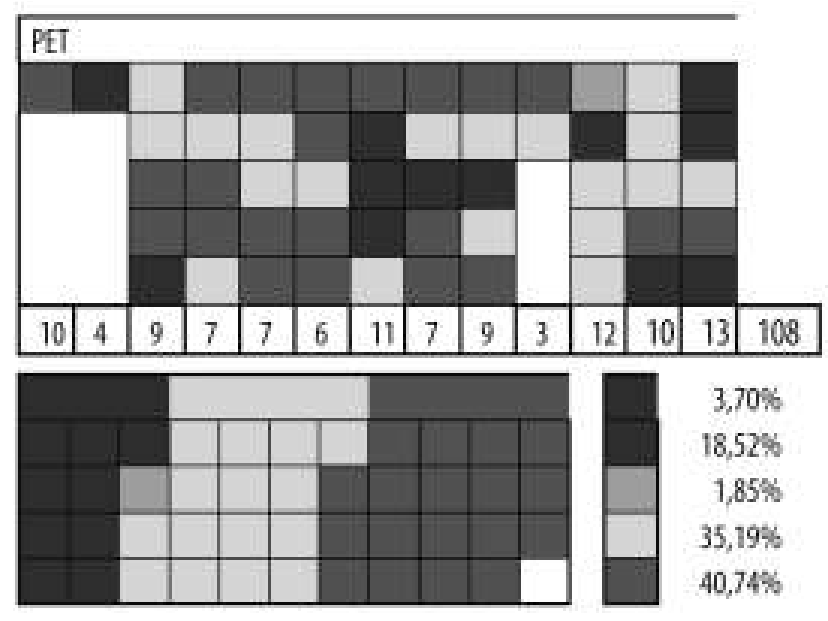

El puntaje deseable se redujo ostensiblemente en comparación con los otros (proporción del $24,07 \%)$. Entre tanto, el puntaje aceptable fue del $35,19 \%$ y el inaceptable representó el $40.74 \%$. Los
108 puntos obtenidos, sobre 175 , conformaron el $61,71 \%$.

\section{TABLA 19. Matriz de comparación de porcentajes y puntajes entre los materiales}

\begin{tabular}{|c|c|c|c|c|c|c|c|}
\hline & $\%$ & NOTA & 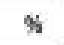 & мота & N6 & NOTA & TOTAL \\
\hline BLANCO & 15 & 105 & 16.7 & 22.3 & 315 & a. & 134 \\
\hline $\begin{array}{l}\text { ESPUMA DE } \\
\text { POLIURETANO (PUR) }\end{array}$ & 3 & 71 A & 24.1 & 33.2 & 24.1 & 332 & 138 \\
\hline $\begin{array}{l}\text { ICOPOR } \\
\text { (POLIESTIRENOPS) }\end{array}$ & 818 & 63 & 370 & 46.3 & 259 & 32,4 & 125 \\
\hline PET & 241 & 30 & 352 & 38.0 & 80,7 & 400 & 108 \\
\hline
\end{tabular}

Fuente: el Estudio (2006).

Así pues, se determinó cuál de los parámetros fue el más influyente en el análisis final. El puntaje favorable, en el caso de la espuma de poliuretano y del blanco (gravilla), fue prácticamente igual; empero, el porcentaje inadecuado del blanco desfavoreció su calificación general.

\section{GRÁFICA 9. Calificación de los materiales en la siguiente etapa con WQI.}

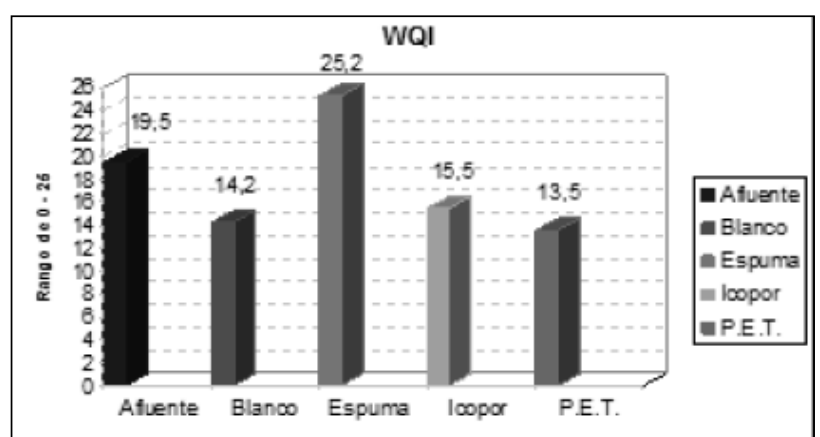

Fuente: el Estudio (2006).

La efectividad del tratamiento, según el método WQI, indica que el agua del afluente se encuentra dentro de un rango de calidad entre 0 y 25 puntos, lo que la ubica como agua inadmisible (ver anexo 2, foto \#3). A su vez, el mejor material como sustento para el biofilm fue la espuma de poliuretano, aunque el agua resultante del tratamiento mediante ésta tampoco estuvo dentro del rango admisible (26pts - 50pts). Así mismo, el blanco 


\section{GRÁFICA 10. Relación entre WQI con DBO ${ }_{5}$ en mayor dilución por material}

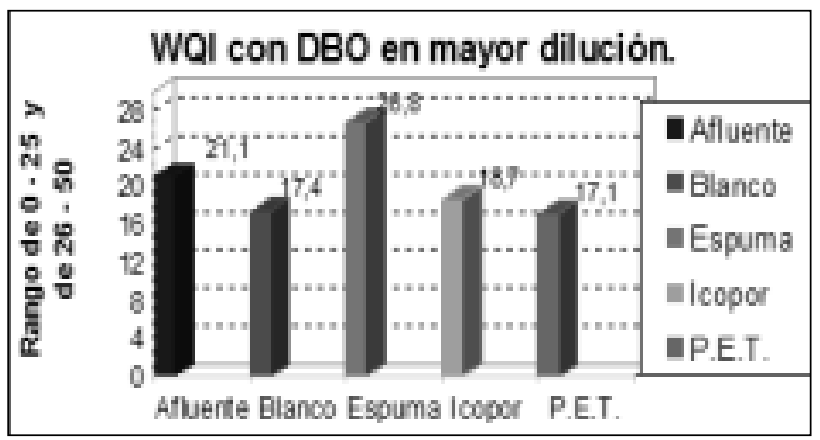

Fuente: el Estudio (2006).

(gravilla), la espuma de poliuretano y el icopor, en vez de mejorar la calidad del agua, la desmejoraron (los resultados fueron más bajos que los del mismo afluente).

El análisis por el método del WQI con relación a la $\mathrm{DBO}_{5}$ permitió establecer que el agua de muestra posee un menor porcentaje en la presencia de bacterias consumidoras de oxigeno, lo que aumenta los valores de oxigeno disuelto, indicando una mejor calidad del agua en éste aspecto. Con base en éstos valores, la espuma de poliuretano cambió de rango y pasó de ser inadmisible a admisible. Además, la proporción de la calidad del agua del afluente es continua en comparación con el resto de los materiales ya que sigue desmejorando (con un valor más alto y más cercano a los valores de 26 puntos en adelante).

Según los resultados de WQI se determinó que el mejor material como sustento para el biofilm es la espuma de poliuretano; aunque no se presentó un cambio muy radical en la calidad del afluente, es un primer paso para la disminución de contaminantes y el mejoramiento del agua.

También se pudo determinar que, a diferencia de materiales tradicionales como sustento para biofilm, el icopor presenta resultados convenientes ya que sobrepasa la calificación en calidad obtenida por el blanco (gravilla). Por su parte, El PET tuvo un desempeño muy bajo como sustento del biofilm; éste no pudo tratar el agua del afluente y, en la mayoría de los parámetros, tuvo una calificación más baja.

Así mismo, el análisis ayudó a diagnosticar el estado de la quebrada Mi Padre Jesús puesto que las descargas recibidas por el cuerpo natural sobrepasaron ampliamente los niveles de autodepuración y su disolución sólo fue mayor durante los periodos más lluviosos - épocas en las que aumenta la descarga de sedimentos en la quebrada.

\section{CONCLUSIONES}

La investigación permitió identificar los factores que afectan a la quebrada Mi Padre Jesús, sobre la cual se presentan descargas de tipo pecuario con una alta carga biológica de sedimentos que reducen su capacidad de resiliencia natural. Incluso, la valoración de la DBO en las fases propuestas por el proyecto, evidenció un comportamiento variable a lo largo del tiempo — siendo permanente un exceso de carga orgánica no tratable en el corto plazo.

Ésta situación de altas cargas biológicas y granulométricas, asociadas al tipo de drenaje (torrencial y de arrastre) de la quebrada, son causas determinantes en la definición del tratamiento secundario requerido. Los filtros percoladores propuestos deben incorporar elementos que permitan la retención de sedimentos gruesos en la fase inicial para facilitar el flujo del agua dentro del filtro propuesto. Entre tanto, el prototipo de filtro percolador permitió identificar variables hidráulicas que serán consideradas en el diseño definitivo del tratamiento de las aguas del cuerpo natural — debe incluir estructuras de pretratamiento o reducir descargas excesivas directamente sobre la corriente.

El diseño propuesto para la evaluación presenta ventajas económicas, operacionales y de mantenimiento del mismo; sin embargo, tal como lo Menciona Winkler (1993), supone algunas dificultades para pronosticar el funcionamiento al interior del filtro (cuyos resultados en laboratorio demuestran esta situación precisa). Así mismo, los tiempos 
de monitoreo son otra característica importante en la funcionalidad del filtro; identificar los tiempos exactos donde se alcanza la maduración del biofilm requiere de la continuidad de muestreo - puede convertirse en una limitante frente a los costos por las rutinas de laboratorio.

Por su parte, las condiciones de calidad de la quebrada Mi Padre Jesús no permiten alcanzar un punto de aguas seguras mediante el tratamiento ofrecido por los filtros; éste sólo logra reducir una parte de la carga total orgánica. Materiales como el residuo de carbón y ladrillo — probados en la fase preliminar - fueron eficientes en la remoción de materia orgánica cercana o ligeramente superior en algunas de las pruebas con respecto a la gravilla (medio convencional). Entre tanto, los resultados alcanzados en el desarrollo de la fase operativa permitieron demostrar que la espuma de poliuretano presenta un mejor comportamiento - por encima del blanco (gravilla)_ en comparación con los materiales evaluados durante la fase preliminar del proyecto. No obstante, el desempeño de ésta espuma tuvo complicaciones en momentos determinados como, por ejemplo, la compactación por el peso del agua y el material, y la colmatación por los sedimentos presentes en el agua (haciendo necesaria la limpieza frecuente); entre otras.

Los resultados anteriores son consecuencia de las características que presenta el material; su porcentaje de vacíos es mayor y permite una mejor adherencia por parte del biofilm. Así mismo, dependiendo del manejo que se le dé a la espuma de poliuretano, puede mejorarse su eficiencia; por ejemplo, al disminuir su tamaño se obtiene una menor área superficial específica, hecho que contribuye en una mejor distribución del biofilm.

En cuanto a la calidad de los materiales se comprobó que los plásticos son más manipulables; debido a su tamaño permiten una mejor distribución en el contenedor y brindan un número mayor de espacios intersticiales para ser llenados por el biofilm.

Luego de comparar los resultados obtenidos en la fase operativa con los de la fase preliminar, se concluyó que los materiales evaluados en esta etapa de la investigación - espuma de poliuretano e icopor- efectúan un mejor desempeño que los materiales residuales probados (específicamente sobre la gravilla).

Las condiciones de distribución de los materiales, las variaciones en la temperatura al interior del filtro y la presencia de zonas muertas, son factores que pueden afectar la eficiencia de los sistemas de tratamiento para aguas residuales con relación al manejo de la carga biológica que pueden filtrar.

\section{RECOMENDACIONES}

Es favorable probar el filtro con una carga estandarizada que facilite la comparabilidad dentro de los tratamientos previstos. Además, será apropiado combinar más de un procedimiento para complementar el tratamiento biológico.

En momentos determinados deberán variarse los parámetros hidráulicos al interior de los filtros con fin de aproximarse al cálculo del tiempo de retención (especialmente frente a las características de porosidad y colmatación presentes) y limitar los lavados; pueden reducir significativamente la formación de biofilm. De hecho, ésta limpieza evita la acumulación de material innecesario dentro del filtro.

Por su parte, resultaría conveniente un estudio sobre la combinación de la espuma de poliuretano con otros materiales que presenten características complementarias para su desempeño como sustrato (icopor, por ejemplo).

Aunque en las dos etapas del proyecto fue imposible realizar un análisis microbiológico adecuado, éste tipo de recurso es tracendental para determinar con exactitud las bacterias, hongos y líquenes —entre otros — existentes en los sustratos a evaluar. Además, permiten identificar con exactitud el grosor de la capa de biofilm y el tiempo en cada una de sus fases (formación, reproducción y muerte).

REVISTA CIENTÍFICA / ENERO -DICIEMBRE DE 2010 / No. 12 / BOGOTÁ, D.C. 


\section{BIBLIOGRAFÍA}

ALVARADO, L. Y PÉREZ, L. (2003), Parámetros de diseño de una planta de aguas residuales para la sede de la facultad del medio ambiente y recursos naturales de la Universidad Distrital Francisco José de Caldas,

ARIAS, E. Y LASTRA, J. (2003), Tratamiento secundario de aguas. [En línea] Consultado Abril de 2006, Disponible en http://www. aguas-monografias_com.htm

AURAZO DE ZUMAETA, M. (2005), Aspectos biológicos de la calidad del agua. [En línea], Consultado Abril de 2006Disponible en <www.bvsde.ops-oms.Org/bvsatr/fulltext/ tratamiento/manualI/ tomoI/dos.pdf $>$

CALDERÓN, F. et al. (2003), Los Sustratos. [En línea], Consultado Abril de 2006 Disponible en http://www.drcalderon labs.com/index.html.

CERVERA, L. et Al. (1999), Evaluación económica y ambiental de las obras de restauración morfológica de la quebrada Mi Padre Jesús o Zanjón de San Martín, Bogotá D.C., trabajo de grado para optar el título de Especialista en Gerencia de recursos naturales. Universidad Distrital Francisco José de Caldas. Facultad del Medio Ambiente y Recursos Naturales

CRITES, R. Y TCHOBANOGLOUS, G. (2000), Sistemas de manejo de aguas residuales para núcleos pequeños y descentralizados, ciudad, MC Graw Hill.

CRUZ, I.; MORENO, L.Y CASTRO, F. (2005), Evaluación de la calidad del agua y diagnóstico ambiental del Humedal Jaboque, Bogotá D.C., Universidad Distrital Francisco José de Caldas. Facultad del Medio Ambiente y Recursos Naturales

Escuela de Ciencias de la Tierra (2000, enero). Tratamiento de aguas blancas y aguas residuales. Universidad de Oriente.
FUSTER, N. (2004), "Observatori de la Seguretat Alimentària Universitat Autònoma de Barcelona" [En línea], Consultado Abril de 2006. Disponible en <http://www.consumaseguridad.com/web/es/ investigacion/ 2004/06/02/12636.php>

GRANJA, A. Y YAGUARA, D. (2004), Evaluación de materiales de la zona Fúquene - Boyacá como medios filtrantes para aguas residuales domésticas, Bogotá D.C., Universidad Distrital Francisco José De Caldas. Facultad del Medio Ambiente y los Recursos Naturales.

HARPER, C. (1995). Hand Book of Plastics, Elastomers and Composites, Washington, Mc Graw Hill.

INSTITUTO COLOMBIANO DE NORMAS Técnicas (2002), Normas colombianas para la presentación de documentación, tesis, trabajos de grado y otros trabajos de investigación, Bogotá D.C., Icontec.

Instructivo del analizador Biotech HMB para bacterias en aguas de enfriamiento. http://www. biotechintl.com /INSTRUCTIVO.html Enero 2000

KAJUMULO, A (202), Uso y reuso de los plásticos en hábitat, ciudad, editorial.

Méndez, C. y Rodríguez, I. (2004). Análisis comparativo entre medios de soporte fijo de plástico, grava y guadua, en reactores anaerobios de flujo a pistón para el tratamiento de agua residual doméstica, Bogotá D.C., Universidad de La Salle, Facultad de Ingeniería Ambiental y Sanitaria.

METCALF y EDDY (1998), Ingeniería de aguas residuales. Tratamiento, vertido y reutilización, ciudad, MC Graw Hill.

Autor, ciudad, Métodos Normalizados para el Análisis de Aguas Potables y Residuales. Ed. Diaz de Santos S.A. 1992 
OSORIO, E. Y GARCÍA, H. (2005), Aprovechamiento de Residuos para la depuración biológica de aguas residuales. Ciudad, Universidad de Granada, Departamento de Ingeniería Civil.

Revista de Biología, Ciencias Experimentales y de la Salud. http://www.biologia-en internet. comdefault.aspId $=23 \& \mathrm{Fd}=2$

RIGOLA, M. (1989), Tratamiento de aguas industriales, aguas de proceso y residuales, Barcelona, Marcombo Boixareu.

ROMERO, J. (2002), Tratamiento de aguas residuales. Teoría y principios de diseño, Bogotá D.C., Escuela Colombiana de Ingeniería., Facultad de

RONZANO, E. (1995), Tratamiento biológico de las aguas residuales, Madrid, Editorial Díaz de Santos S.A.
SANTOS, E. (1998), Tratamiento del agua por procesos de membrana / Principios, procesos y aplicaciones. American Water Works Mc Graw Hill. Estados Unidos de América.

- (2002), Calidad y tratamiento del agua. Manual de suministros de agua comunitaria. American Water Works Mc Graw Hill Profesional. Estados Unidos de América,

(2003).Aguas Residuales. Contaminación. Uso urbano e industrial de agua. Contaminantes hidrológicos. Lodos. Arcilla expandida. Electrocoagulación. Depuración [En línea], Consultado Abril de 2006. Disponible en http://html. monografias.com/aguas-residuales_3.html

Tabla de Clasificación de Plásticos y su uso en reciclaje. www.ereciclaje.com

WINKLER, M. (1986), Tratamiento Biológico de Aguas de Desecho, ciudad, editorial. 


\section{ANEXOS}

\section{ANEXO 1. Matriz de análisis de ensayos para la fase preliminar. Pruebas de laboratorio efectuadas al filtro percolador en la fase preliminar.}

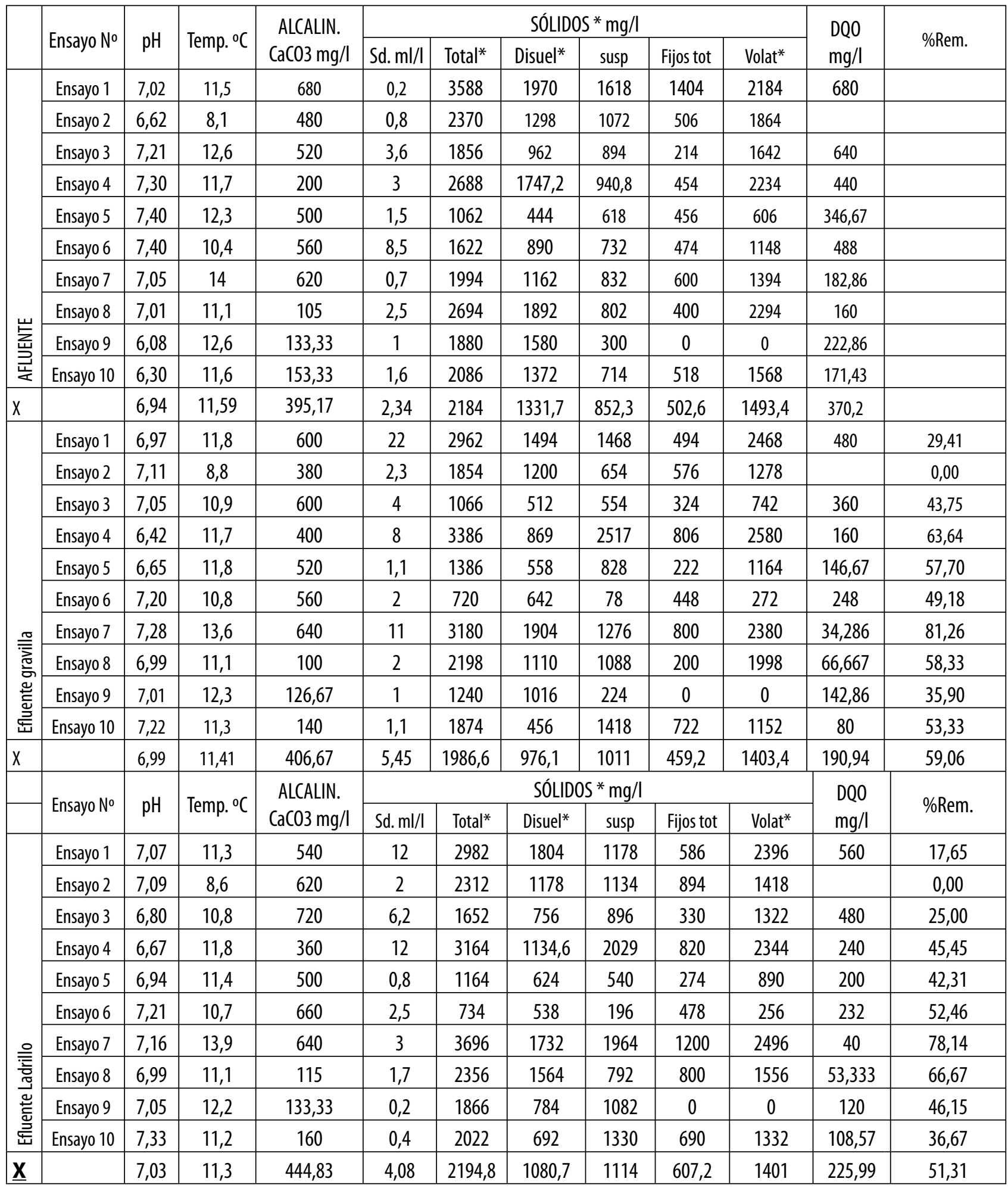


HELMUT ESPINOSA GARCÍA - VILMA HERNÁNDEZ MONTAÑA - NELLY P. LOZANO PUENTES - JOHANA TAVERA TAVERA - ALEXIS CERVERA BONILLA - ADRIANA GRANJA RODRÍGUEZ - DIDIER YAGÜARÁ

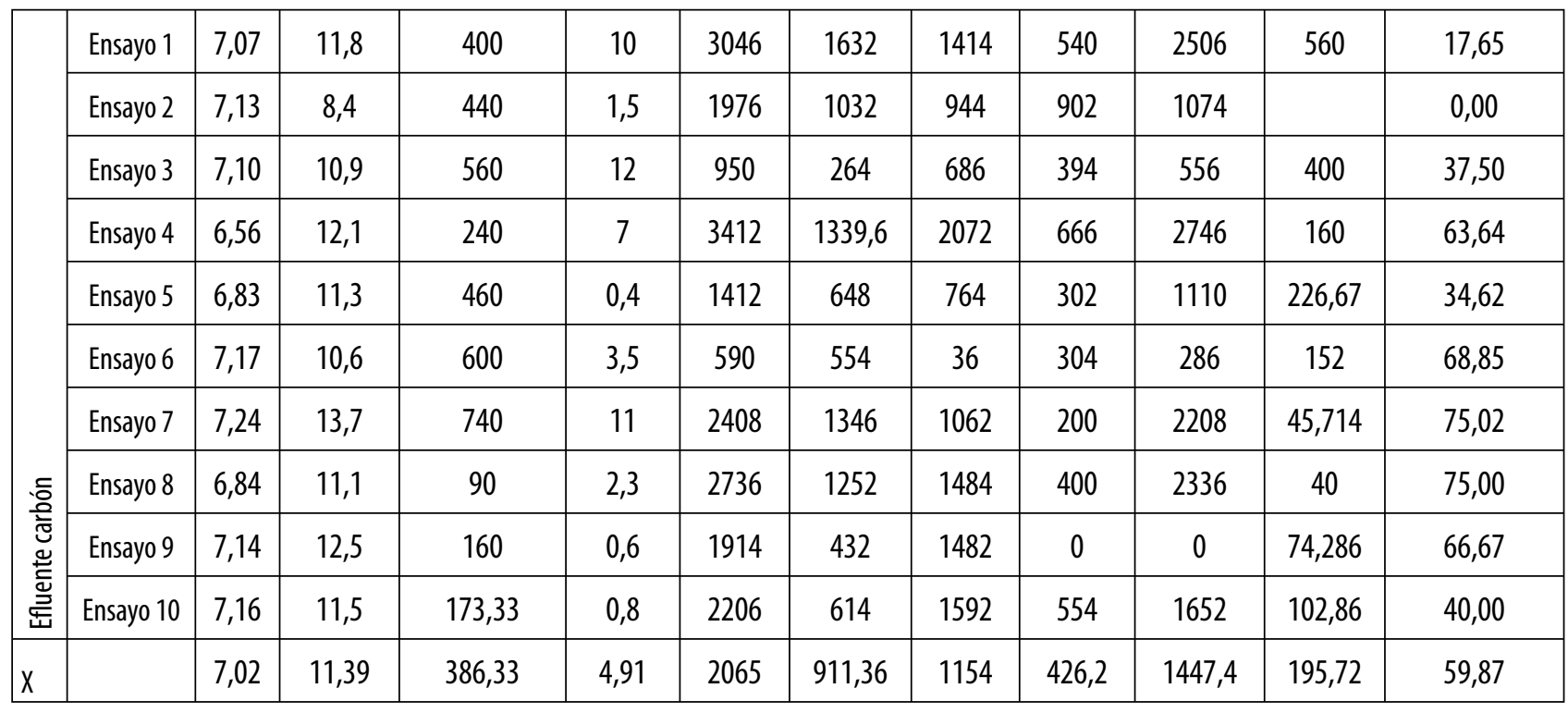

Fuente: la investigación. Adaptado de Granja y Yaguara (2004).

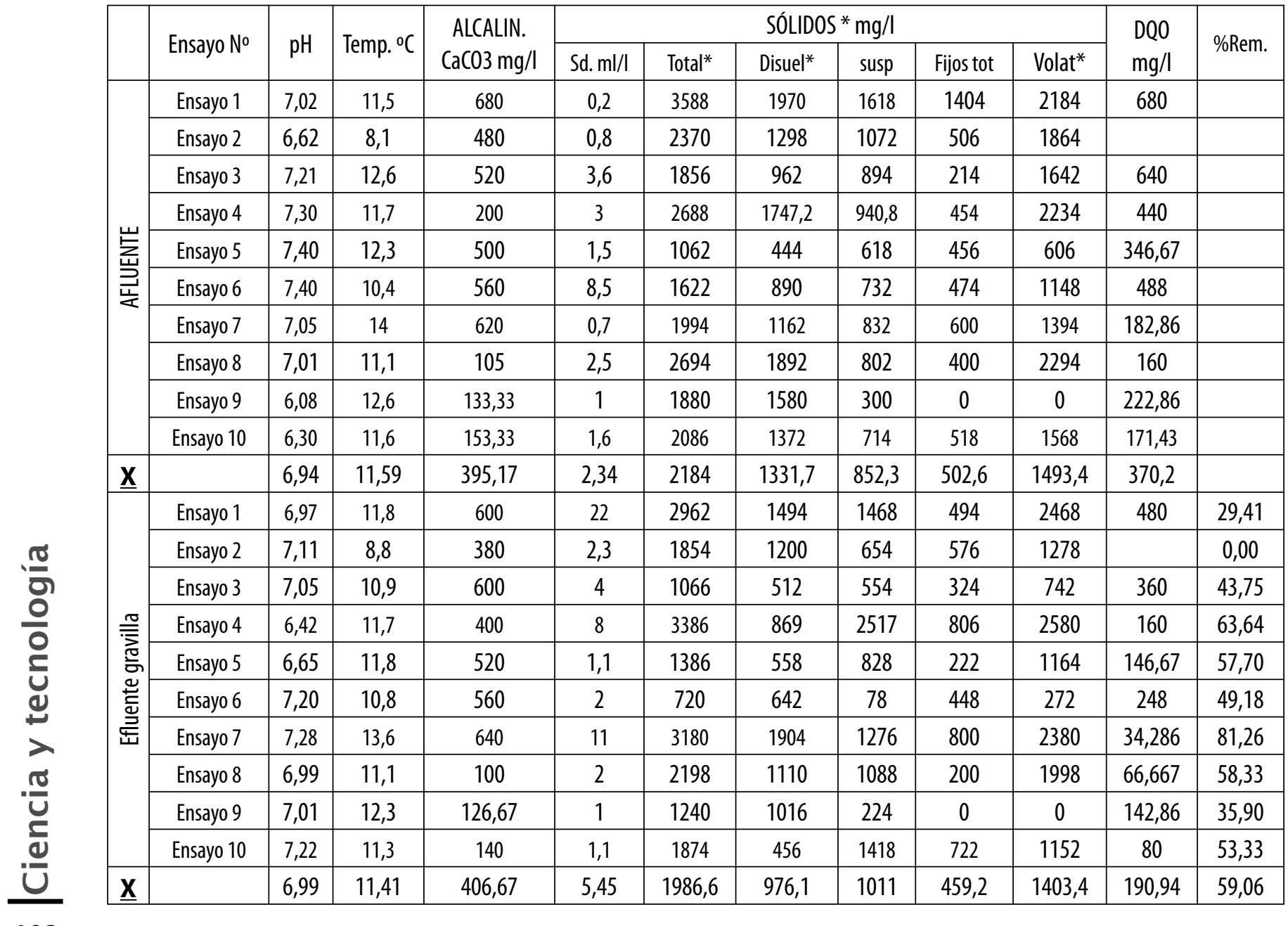




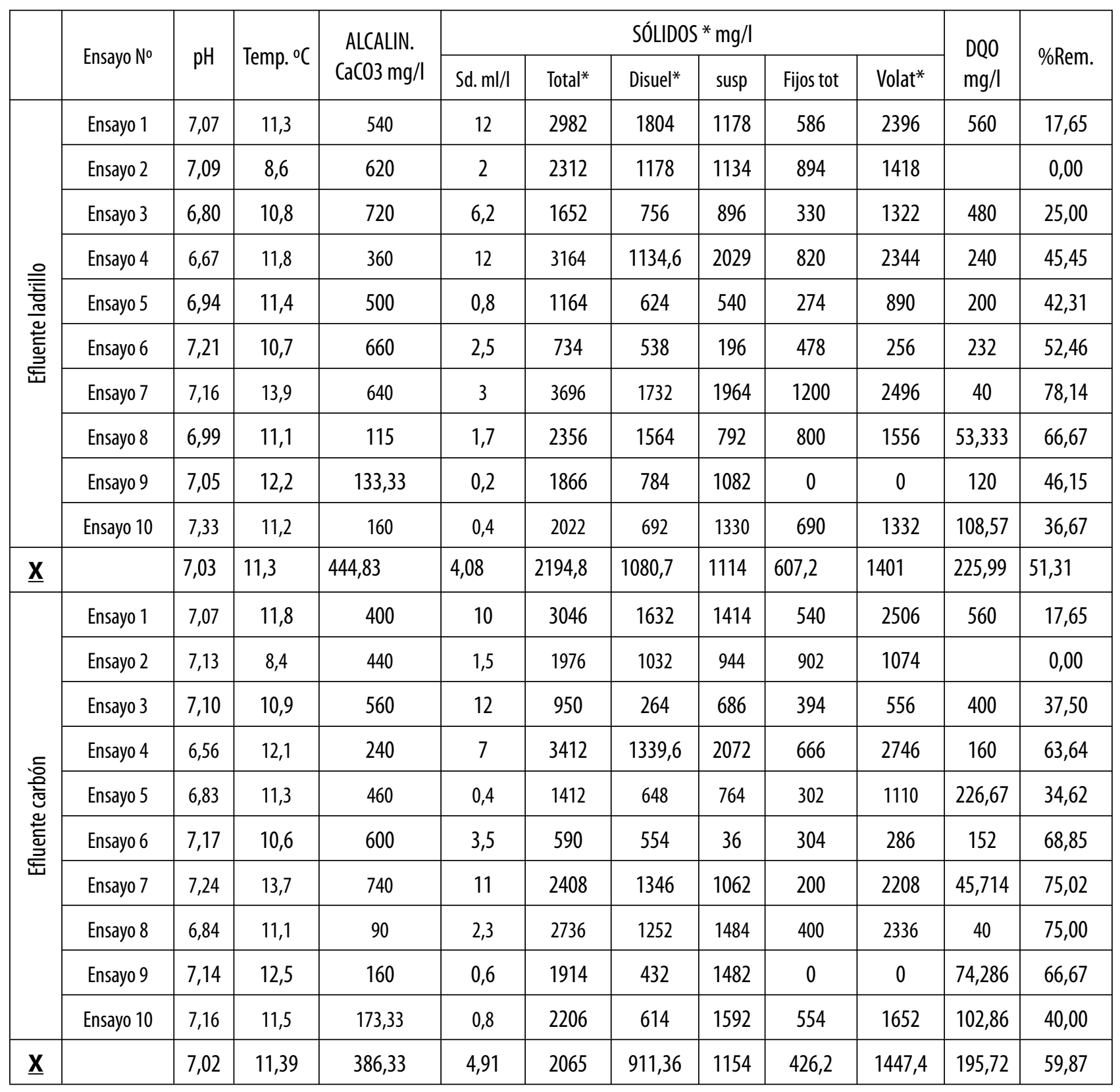

Fuente: los autores (2004). 


\section{$\overrightarrow{\$}$ |Ciencia y tecnología}

\section{ANEXO 2. Resultados de las pruebas de laboratorio en la fase operativa.}

\begin{tabular}{|c|c|c|c|c|c|c|c|c|c|c|}
\hline & \multicolumn{10}{|c|}{ TURBIDEZ } \\
\hline & Prueba 1 & Prueba 2 & Prueba 3 & Prueba 5 & Prueba 6 & Prueba 7 & Prueba 8 & Prueba 9 & Prueba 10 & Promedios \\
\hline Afluente & 104 & 40 & 134 & 83 & 265 & 102 & 76 & 55 & 113 & 108,00 \\
\hline Blanco & 115 & 47 & 75 & 89 & 204 & 193 & 65 & 104 & 193 & 120,56 \\
\hline Espuma & 84 & 94 & 54 & 83 & 205 & 164 & 50 & 32 & 66 & 92,44 \\
\hline Icopor & 83 & 66 & 107 & 77 & 126 & 156 & 71 & 79 & 89 & 94,89 \\
\hline PET & 92 & 136 & 37 & 74 & 186 & 161 & 63 & 48 & 68 & 96,11 \\
\hline
\end{tabular}

\begin{tabular}{|c|c|c|c|c|c|c|c|c|c|c|c|}
\hline & \multicolumn{11}{|c|}{ TEMPERATURA } \\
\hline & Prueba 1 & Prueba 2 & Prueba 3 & Prueba 4 & Prueba 5 & Prueba 6 & Prueba 7 & Prueba 8 & Prueba 9 & Prueba 10 & Promedio \\
\hline Afluente & 14 & 14 & 15 & 12,5 & 14 & 15 & 15 & 14,5 & 18 & 15,5 & 14,75 \\
\hline Blanco & 14 & 14 & 14 & 11 & 13,5 & 15 & 14,5 & 14,5 & 18,5 & 16 & 14,5 \\
\hline Espuma & 14 & 14 & 14 & 11 & 12,5 & 15 & 14 & 14 & 18 & 15,5 & 14,2 \\
\hline Icopor & 14 & 14 & 15 & 11 & 13 & 15 & 15 & 15,5 & 18 & 17,5 & 14,8 \\
\hline PET & 14 & 14 & 14 & 10 & 12,5 & 15 & 14,5 & 14 & 18,5 & 15 & 14,15 \\
\hline
\end{tabular}

\begin{tabular}{|c|c|c|c|c|c|c|c|c|c|c|}
\hline & \multicolumn{10}{|c|}{$\mathrm{pH}$} \\
\hline & $\begin{array}{c}\text { Prueba } \\
1\end{array}$ & Prueba 2 & Prueba 3 & Prueba 4 & Prueba 5 & Prueba 6 & Prueba 7 & Prueba 8 & Prueba 9 & Prueba 10 \\
\hline Afluente & 6,61 & 6,37 & 6,55 & 6,56 & 6,27 & 6,28 & 6,98 & 6,56 & 6,68 & 6,77 \\
\hline Blanco & 6,35 & 6,06 & 6,33 & 6,40 & 6,25 & 6,55 & 6,48 & 6,32 & 6,30 & 6,19 \\
\hline Espuma & 6,40 & 5,93 & 6,26 & 6,37 & 6,30 & 6,33 & 6,15 & 6,29 & 6,49 & 6,37 \\
\hline Icopor & 6,34 & 5,75 & 6,09 & 6,54 & 6,39 & 6,38 & 6,40 & 6,30 & 6,44 & 6,41 \\
\hline \multirow[t]{3}{*}{ PET } & 6,31 & 5,89 & 6,10 & 6,48 & 6,19 & 6,43 & 6,20 & 6,24 & 6,35 & 6,27 \\
\hline & \multicolumn{10}{|c|}{ COLOR } \\
\hline & Prueba 1 & Prueba 2 & Prueba 3 & Prueba 5 & Prueba 6 & Prueba 7 & Prueba 8 & Prueba 9 & Prueba 10 & Promedio \\
\hline Afluente & 414 & 231 & 126 & 83 & 916 & 98 & 86 & 61 & 58 & 230,333 \\
\hline Blanco & 261 & 291 & 72 & 74 & 360 & 163 & 78 & 97 & 154 & 172,222 \\
\hline Espuma & 70 & 474 & 73 & 77 & 368 & 153 & 81 & 53 & 72 & 157,889 \\
\hline
\end{tabular}




\begin{tabular}{|c|c|c|c|c|c|c|c|c|c|c|c|}
\hline Icopor & 64 & 349 & 134 & 83 & 244 & 142 & 84 & 80 & 86 & 140,667 & \\
\hline \multirow[t]{3}{*}{ PET } & 77 & 701 & 71 & 89 & 336 & 146 & 84 & 66 & 75 & 182,778 & \\
\hline & \multicolumn{10}{|c|}{ CONDUCTIVIDAD } & \\
\hline & Prueba 2 & Prueba 3 & Prueba 4 & Prueba 5 & Prueba 6 & Prueba 7 & Prueba 8 & Prueba 9 & Prueba 10 & Promedio & \\
\hline Afluente & 214 & 277 & 1829 & 276 & 211 & 289 & 246 & 357 & 209 & 434,222 & \\
\hline Blanco & 243 & 280 & 908 & 402 & 247 & 346 & 288 & 334 & 209 & 361,889 & \\
\hline Espuma & 296 & 284 & 793 & 425 & 301 & 568 & 352 & 398 & 236 & 405,889 & \\
\hline Icopor & 254 & 388 & 763 & 391 & 275 & 404 & 320 & 341 & 211 & 371,889 & \\
\hline \multirow[t]{3}{*}{ PET } & 350 & 308 & 760 & 426 & 342 & 679 & 399 & 411 & 288 & 440,333 & \\
\hline & \multicolumn{9}{|c|}{ ACIDEZ } & & \\
\hline & Prueba 1 & Prueba 2 & Prueba 3 & Prueba 4 & Prueba 7 & Prueba 8 & Prueba 9 & $\begin{array}{c}\text { Prueba } \\
10 \\
\end{array}$ & Promedio & & \\
\hline Afluente & 165 & 42,5 & 80 & 230 & 100,1 & 148 & 16,5 & 18,5 & 100,075 & & \\
\hline Espuma & 160 & 72,5 & 45 & 100 & 90,3 & 226 & 28 & 0,5 & 90,2875 & & \\
\hline Icopor & 115 & 52,5 & 85 & 90 & 93,1 & 282 & 26,5 & 0,5 & 93,075 & & \\
\hline \multirow[t]{3}{*}{ PET } & 135 & 80 & 70 & 110 & 104,8 & 268 & 70,5 & 0,5 & 104,85 & & \\
\hline & \multicolumn{9}{|c|}{ ALCALINIDAD } & & \\
\hline & Prueba 1 & Prueba 2 & Prueba 3 & Prueba 4 & Prueba 7 & Prueba 8 & Prueba 9 & $\begin{array}{c}\text { Prueba } \\
10\end{array}$ & Promedio & & \\
\hline Afluente & 110 & 57,5 & 20 & 45 & 4 & 26 & 5 & 6,5 & 34,25 & & \\
\hline Blanco & 30 & 90 & 20 & 20 & 11 & 46 & 5,5 & 9 & 28,94 & & \\
\hline Espuma & 55 & 105 & 25 & 25 & 12 & 42 & 7,5 & 6 & 34,69 & & \\
\hline Icopor & 25 & 95 & 20 & 20 & 5 & 44 & 4,5 & 6 & 27,44 & & \\
\hline \multirow[t]{3}{*}{ PET } & 90 & 50 & 25 & 25 & 10 & 48 & 11 & 10,5 & 33,69 & & \\
\hline & \multicolumn{11}{|c|}{ DUREZA TOTAL } \\
\hline & Prueba 1 & Prueba 2 & Prueba 3 & Prueba 4 & Prueba 5 & Prueba 6 & Prueba 7 & Prueba 8 & Prueba 9 & Prueba 10 & Promedio \\
\hline Espuma & 130 & 102,500 & 60 & 185 & 145 & 50 & 215 & 155 & 115 & 85 & 124,25 \\
\hline
\end{tabular}

\section{$\overrightarrow{\mathrm{v}}$ |Ciencia y tecnología}




\section{ฉ̊ |Ciencia y tecnología}

\begin{tabular}{|c|c|c|c|c|c|c|c|c|c|c|c|}
\hline Icopor & 325 & 127,500 & 40 & 150 & 80 & 115 & 75 & 130 & 80 & 125 & 124,75 \\
\hline PET & 240 & 110 & 55 & 160 & 145 & 175 & 130 & 140 & 110 & 145 & 141 \\
\hline
\end{tabular}

\begin{tabular}{|c|c|c|c|c|c|c|c|c|c|c|c|}
\hline & \multicolumn{11}{|c|}{ DUREZA CÁLCICA } \\
\hline & Prueba 1 & Prueba 2 & Prueba 3 & Prueba 4 & Prueba 5 & Prueba 6 & Prueba 7 & Prueba 8 & Prueba 9 & Prueba 10 & Promedio \\
\hline Afluente & 130 & 52,500 & 50 & 22,5 & 70 & 110 & 25 & 35 & 15 & 10 & 52 \\
\hline Blanco & 90 & 75,000 & 45 & 25 & 45 & 35 & 25 & 25 & 20 & 25 & 41 \\
\hline Espuma & 55 & 102,500 & 20 & 35 & 120 & 40 & 35 & 20 & 25 & 5 & 45,75 \\
\hline Icopor & 55 & 87,500 & 35 & 25 & 70 & 30 & 20 & 20 & 15 & 5 & 36,25 \\
\hline PET & 5 & 82,500 & 25 & 17,5 & 105 & 80 & 15 & 20 & 10 & 20 & 42,5 \\
\hline & \multicolumn{11}{|c|}{ DUREZA MAGNÉSICA } \\
\hline$* * 1$ & $\begin{array}{c}\text { Prueba } \\
1 \\
\end{array}$ & Prueba 2 & Prueba 3 & Prueba 4 & Prueba 5 & Prueba 6 & Prueba 7 & Prueba 8 & Prueba 9 & Prueba 10 & Promedio \\
\hline Afluente & 1,216 & 1,216 & 3,647 & 68,676 & 4,862 & 24,310 & 6,078 & 18,233 & 21,879 & 17,017 & 16,713 \\
\hline Blanco & 18,233 & 14,586 & 3,647 & 41,327 & 12,155 & 23,095 & 9,724 & 18,233 & 10,940 & 12,155 & 16,410 \\
\hline Espuma & 18,233 & 0,000 & 9,724 & 36,465 & 6,078 & 2,431 & 43,758 & 32,819 & 21,879 & 19,448 & 19,084 \\
\hline Icopor & 65,637 & 9,724 & 1,216 & 30,388 & 2,431 & 20,664 & 13,371 & 26,741 & 15,802 & 29,172 & 21,515 \\
\hline PET & 46,189 & 6,685 & 7,293 & 34,642 & 9,724 & 23,095 & 27,957 & 29,172 & 24,310 & 30,388 & 23,946 \\
\hline
\end{tabular}

\begin{tabular}{|c|c|c|c|c|c|c|c|c|c|c|c|}
\hline & \multicolumn{11}{|c|}{ SÓLIDOS SEDIMENTABLES } \\
\hline & Prueba 1 & Prueba 2 & Prueba 3 & Prueba 4 & Prueba 5 & Prueba 6 & Prueba 7 & Prueba 8 & Prueba 9 & Prueba 10 & Promedio \\
\hline Afluente & 72 & 0,600 & 2,25 & 29,59 & 1 & 22,05 & 1,3 & 0,6 & 0,9 & 0,2 & 13,05 \\
\hline Blanco & 27 & 1,000 & 0,7 & 5 & 1,2 & 14 & 0 & 0,9 & 3,5 & 5,5 & 5,88 \\
\hline Espuma & 74 & 3,600 & 0,6 & 5 & 0 & 17 & 2,4 & 0 & 0 & 0,7 & 10,33 \\
\hline Icopor & 16 & 1,800 & 1,6 & 0,8 & 0,2 & 17 & 2,4 & 0,1 & 5 & 0,6 & 4,55 \\
\hline PET & 33 & 4,500 & 0,4 & 0,8 & 0,2 & 9 & 2,5 & 0,6 & 0,2 & 0,2 & 5,14 \\
\hline
\end{tabular}

\begin{tabular}{|c|c|c|c|c|c|c|c|c|c|c|c|}
\hline & \multicolumn{11}{|c|}{ SÓLIDOS TOTALES (gráfica 4 A) } \\
\hline & Prueba 1 & Prueba 2 & Prueba 3 & Prueba 4 & Prueba 5 & Prueba 6 & \begin{tabular}{|l|} 
Prueba 7 \\
\end{tabular} & Prueba 8 & Prueba 9 & Prueba 10 & Promedio \\
\hline Afluente & 516 & 780 & 7050 & 31150 & 650 & 36650 & 2300 & 1500 & 4600 & 3100 & 8830 \\
\hline Blanco & 242 & 900 & 4450 & 12700 & 1350 & 3050 & 2050 & 1450 & 1500 & 2050 & 2974 \\
\hline Espuma & 448 & 1320 & 3950 & 8000 & 1400 & 4250 & 1900 & 1500 & 5550 & 800 & 2912 \\
\hline Icopor & 636 & 695 & 8200 & 10100 & 1250 & 4000 & 2150 & 2450 & 1400 & 900 & 3178 \\
\hline PET & 316 & 1040 & 33450 & 8050 & 1300 & 4150 & 1650 & 1500 & 6750 & 700 & 5891 \\
\hline
\end{tabular}




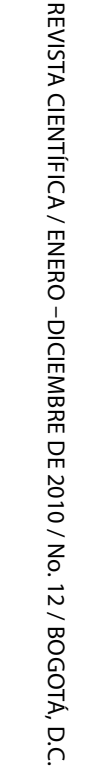

\begin{tabular}{|c|c|c|c|c|c|c|c|c|c|c|c|}
\hline & \multicolumn{11}{|c|}{ SÓLIDOS TOTALES (gráfica 4B) } \\
\hline & Prueba 1 & Prueba 2 & Prueba 3 & Prueba 4 & Prueba 5 & Prueba 6 & Prueba 7 & Prueba 8 & Prueba 9 & Prueba 10 & Promedio \\
\hline Afluente & 516 & 780 & 7050 & 5738 & 650 & 6350 & 2300 & 1500 & 4600 & 3100 & 3258 \\
\hline Blanco & 242 & 900 & 4450 & 12700 & 1350 & 3050 & 2050 & 1450 & 1500 & 2050 & 2974 \\
\hline Espuma & 448 & 1320 & 3950 & 8000 & 1400 & 4250 & 1900 & 1500 & 5550 & 800 & 2912 \\
\hline Icopor & 636 & 695 & 8200 & 10100 & 1250 & 4000 & 2150 & 2450 & 1400 & 900 & 3178 \\
\hline PET & 316 & 1040 & 5891 & 8050 & 1300 & 4150 & 1650 & 1500 & 6750 & 700 & 3135 \\
\hline
\end{tabular}

\begin{tabular}{|c|c|c|c|c|c|c|c|c|c|c|c|}
\hline & \multicolumn{11}{|c|}{ SÓLIDOS TOTALES DISUELTOS } \\
\hline & Prueba 1 & Prueba 2 & Prueba 3 & Prueba 4 & Prueba 5 & Prueba 6 & Prueba 7 & Prueba 8 & Prueba 9 & Prueba 10 & Promedio \\
\hline Afluente & 860 & 305 & 2750 & 3100 & 1050 & 5100 & 1000 & 850 & 1000 & 1150 & 1716,500 \\
\hline Blanco & 1740 & 350 & 2500 & 1000 & 1150 & 700 & 1450 & 400 & 2200 & 2050 & 1354 \\
\hline Espuma & 628 & 390 & 2650 & 700 & 1000 & 1280 & 1150 & 300 & 1250 & 1450 & 1079,800 \\
\hline Icopor & 600 & 335 & 3100 & 700 & 850 & 960 & 1000 & 850 & 2100 & 1100 & 1159,500 \\
\hline PET & 670 & 430 & 19950 & 700 & 900 & 1080 & 1200 & 750 & 1850 & 550 & 2808 \\
\hline
\end{tabular}

\begin{tabular}{|c|c|c|c|c|c|c|c|c|c|c|c|}
\hline & \multicolumn{11}{|c|}{ SÓLIDOS TOTALES SUSPENDIDOS } \\
\hline & Prueba 1 & Prueba 2 & Prueba 3 & Prueba 4 & Prueba 5 & Prueba 6 & Prueba 7 & Prueba 8 & Prueba 9 & Prueba 10 & Promedio \\
\hline Afluente & 1302 & 475 & 340 & 3889 & 1540 & 9200 & 1520 & 2220 & 1750 & 200 & 2244 \\
\hline Blanco & 761 & 550 & 2180 & 6380 & 600 & 14 & 1780 & 1000 & 2800 & 200 & 1627 \\
\hline Espuma & 1398 & 930 & 2760 & 2000 & 3020 & 17 & 880 & 3000 & 200 & 800 & 1501 \\
\hline Icopor & 1244 & 360 & 2740 & 2460 & 480 & 9 & 1040 & 3220 & 350 & 600 & 1250 \\
\hline PET & 1482 & 610 & 2140 & 240 & 340 & 56 & 3140 & 4880 & 650 & 200 & 1374 \\
\hline
\end{tabular}

\begin{tabular}{|c|c|c|c|c|c|c|c|c|c|c|c|}
\hline & \multicolumn{11}{|c|}{ SÓLIDOS TOTALES FIJOS } \\
\hline & Prueba 1 & Prueba 2 & Prueba 3 & Prueba 4 & Prueba 5 & Prueba 6 & Prueba 7 & Prueba 8 & Prueba 9 & Prueba 10 & Promedio \\
\hline Afluente & 516 & 440 & 4700 & 7800 & 200 & 5450 & 950 & 50 & 2100 & 1700 & 2390,600 \\
\hline Blanco & 242 & 465 & 2800 & 8600 & 650 & 650 & 1150 & 1100 & 300 & 750 & 1670,700 \\
\hline Espuma & 448 & 840 & 2250 & 5200 & 600 & 1050 & 750 & 250 & 3200 & 500 & 1508,800 \\
\hline Icopor & 636 & 380 & 5550 & 6750 & 1000 & 550 & 1100 & 490 & 650 & 700 & 1780,600 \\
\hline PET. & 316 & 560 & 3850 & 5950 & 700 & 550 & 550 & 350 & 3750 & 350 & 1692,600 \\
\hline
\end{tabular}

\section{SÓLIDOS TOTALES VOLÁTILES}

\begin{tabular}{|l|c|c|c|c|c|c|c|c|c|c|}
\hline Prueba 1 & Prueba 2 & Prueba 3 & Prueba 4 & Prueba 5 & Prueba 6 & Prueba 7 & Prueba 8 & Prueba 9 & Prueba 10 & Promedio
\end{tabular}

\section{$\vec{\rho}$ |Ciencia y tecnología}




\section{$\vec{\triangleright}$ |Ciencia y tecnología}

\begin{tabular}{|c|c|c|c|c|c|c|c|c|c|c|c|}
\hline Afluente & 2442 & 340 & 2350 & 7800 & 450 & 5128 & 1350 & 1450 & 2500 & 1400 & 2521 \\
\hline Blanco & 846 & 435 & 1750 & 4100 & 700 & 2400 & 900 & 350 & 1200 & 1300 & 1398 \\
\hline Espuma & 1026 & 480 & 1400 & 2800 & 800 & 3200 & 1150 & 1250 & 2350 & 300 & 1476 \\
\hline Icopor & 1496 & 315 & 2650 & 3350 & 250 & 3450 & 1050 & 1960 & 750 & 200 & 1547 \\
\hline PET & 772 & 480 & 4275 & 2100 & 600 & 3600 & 1100 & 1150 & 3000 & 350 & 1743 \\
\hline
\end{tabular}

\begin{tabular}{|c|c|c|c|c|c|c|c|c|c|c|c|}
\hline \multirow[t]{2}{*}{2} & \multicolumn{11}{|c|}{ SÓLIDOS TOTALES VOLÁTILES } \\
\hline & Prueba 1 & Prueba 2 & Prueba 3 & Prueba 4 & Prueba 5 & Prueba 6 & Prueba 7 & Prueba 8 & Prueba 9 & Prueba 10 & Promedio \\
\hline Afluente & 2442 & 340 & 2350 & 7800 & 450 & 31200 & 1350 & 1450 & 2500 & 1400 & 5128 \\
\hline Blanco & 846 & 435 & 1750 & 4100 & 700 & 2400 & 900 & 350 & 1200 & 1300 & 1398 \\
\hline Espuma & 1026 & 480 & 1400 & 2800 & 800 & 3200 & 1150 & 1250 & 2350 & 300 & 1476 \\
\hline Icopor & 1496 & 315 & 2650 & 3350 & 250 & 3450 & 1050 & 1960 & 750 & 200 & 1547 \\
\hline PET & 772 & 480 & 29600 & 2100 & 600 & 3600 & 1100 & 1150 & 3000 & 350 & 4275 \\
\hline
\end{tabular}

\begin{tabular}{|c|c|c|c|c|c|c|c|c|c|c|c|}
\hline & \multicolumn{11}{|c|}{ DQ0 (gráfica $6 \mathrm{~A}$ ) } \\
\hline & Prueba 1 & Prueba 2 & Prueba 3 & Prueba 4 & Prueba 5 & Prueba 6 & Prueba 7 & Prueba 8 & Prueba 9 & Prueba 10 & Promedio \\
\hline Afluente & 6280 & 48 & 128 & 84000 & 206,667 & 14800 & 160 & 420 & 60 & 280 & 10638,27 \\
\hline Espuma & 3280 & 456 & 96 & 62000 & 93,333 & 1600 & 680 & 320 & 640 & 500 & 6966,53 \\
\hline Icopor & 3960 & 352 & 232 & 84000 & 233,333 & 12800 & 600 & 320 & 1280 & 340 & 10411,73 \\
\hline PET & 3880 & 376 & 200 & 84000 & 200 & 2400 & 560 & 380 & 360 & 560 & 9291,60 \\
\hline
\end{tabular}

\begin{tabular}{|c|c|c|c|c|c|c|c|c|c|c|}
\hline & \multicolumn{10}{|c|}{ DQ0 (gráfica 6 B) } \\
\hline & Prueba 1 & Prueba 2 & Prueba 3 & Prueba 5 & Prueba 6 & Prueba 7 & Prueba 8 & Prueba 9 & Prueba 10 & Promedio \\
\hline Afluente & 6280 & 48 & 128 & 206,667 & 14800 & 160 & 420 & 60 & 280 & $2.486,96$ \\
\hline Blanco & 5560 & 376 & 40 & 280 & 8400 & 400 & 180 & 240 & 520 & $1.777,33$ \\
\hline Espuma & 3280 & 456 & 96 & 93,333 & 1600 & 680 & 320 & 640 & 500 & 851,70 \\
\hline Icopor & 3960 & 352 & 232 & 233,333 & 12800 & 600 & 320 & 1280 & 340 & $2.235,26$ \\
\hline PET & 3880 & 376 & 200 & 200 & 2400 & 560 & 380 & 360 & 560 & 990,67 \\
\hline
\end{tabular}




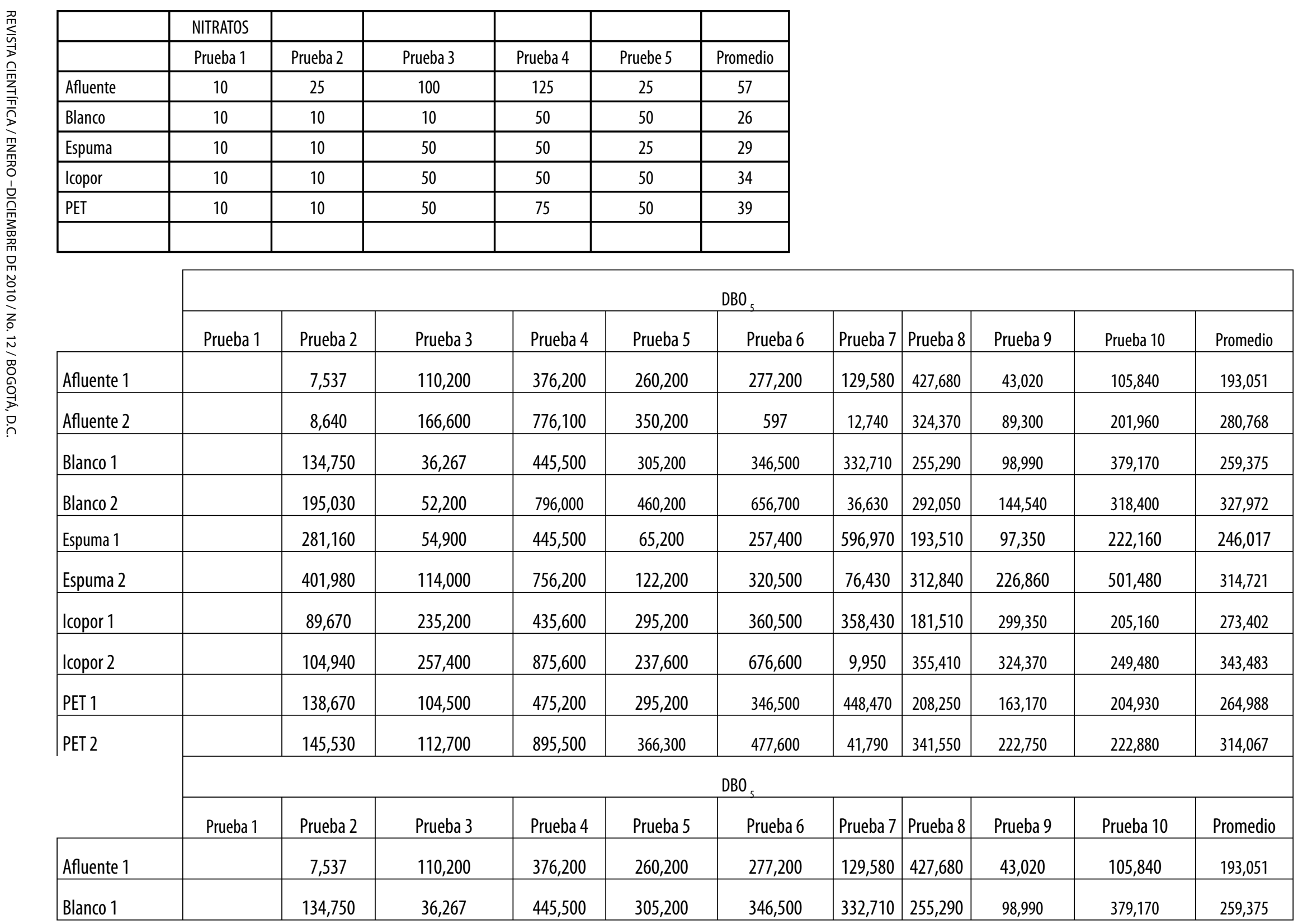

\section{ఫ |Ciencia y tecnología}




\section{$\vec{\partial}$ |Ciencia y tecnología}

\begin{tabular}{|c|c|c|c|c|c|c|c|c|c|c|c|}
\hline Espuma 1 & & 281,160 & 54,900 & 445,500 & 65,200 & 257,400 & 596,970 & 193,510 & 97,350 & 222,160 & 246,017 \\
\hline Icopor 1 & & 89,670 & 235,200 & 435,600 & 295,200 & 360,500 & 358,430 & 181,510 & 299,350 & 205,160 & 273,402 \\
\hline \multirow[t]{3}{*}{ PET 1} & & 138,670 & 104,500 & 475,200 & 295,200 & 346,500 & 448,470 & 208,250 & 163,170 & 204,930 & 264,988 \\
\hline & \multicolumn{11}{|c|}{$\mathrm{DBO}_{5}$} \\
\hline & Prueba 1 & Prueba 2 & Prueba 3 & Prueba 4 & Prueba 5 & Prueba 6 & Prueba 7 & Prueba 8 & Prueba 9 & Prueba 10 & Promedio \\
\hline Afluente 2 & & 8,640 & 166,600 & 776,100 & 350,200 & 597 & 12,740 & 324,370 & 89,300 & 201,960 & 280,768 \\
\hline Blanco 2 & & 195,030 & 52,200 & 796,000 & 460,200 & 656,700 & 36,630 & 292,050 & 144,540 & 318,400 & 327,972 \\
\hline Espuma 2 & & 401,980 & 114,000 & 756,200 & 122,200 & 320,500 & 76,430 & 312,840 & 226,860 & 501,480 & 314,721 \\
\hline Icopor 2 & & 104,940 & 257,400 & 875,600 & 237,600 & 676,600 & 9,950 & 355,410 & 324,370 & 249,480 & 343,483 \\
\hline PET 2 & & 145,530 & 112,700 & 895,500 & 366,300 & 477,600 & 41,790 & 341,550 & 222,750 & 222,880 & 314,067 \\
\hline
\end{tabular}

Fuente: el Estudio (2006).
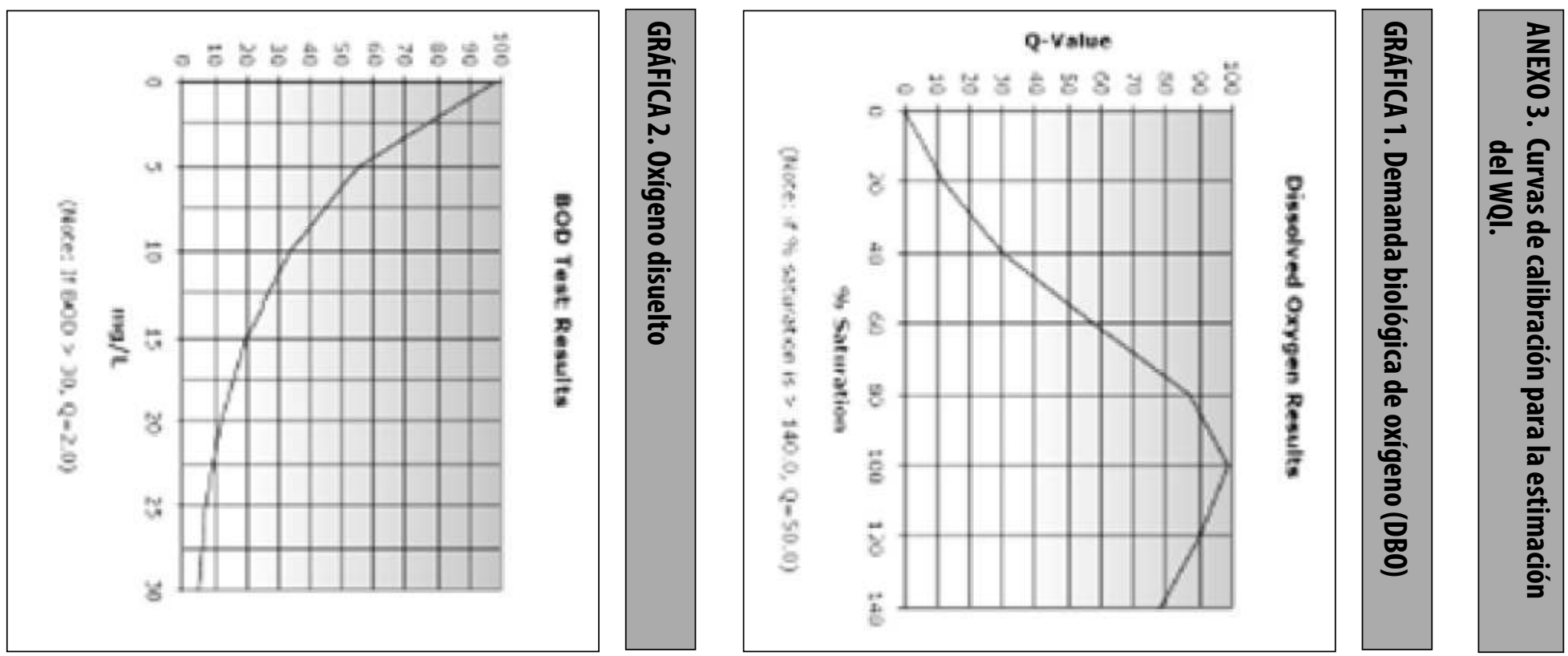


\section{GRÁFICA 3. Coliformes fecales}

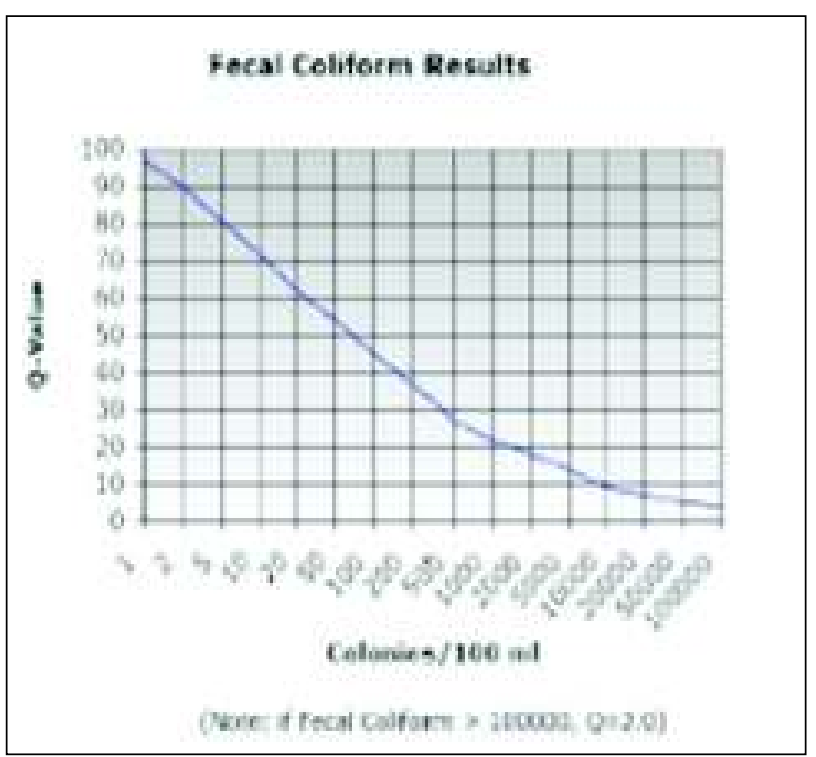

\section{GRÁFICA 4. Nitratos}

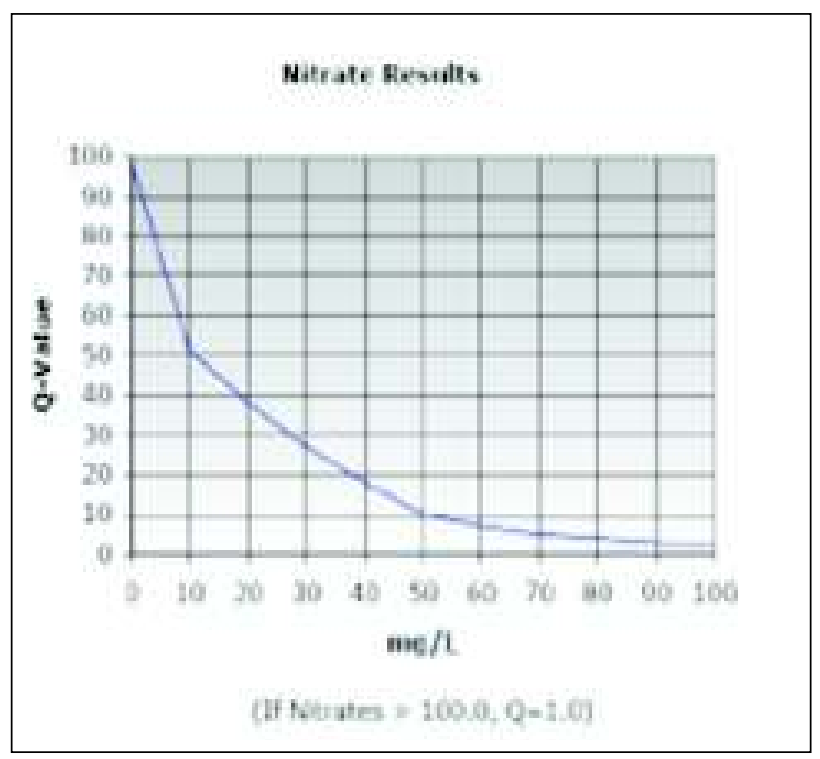

GRÁFICA 5. pH.

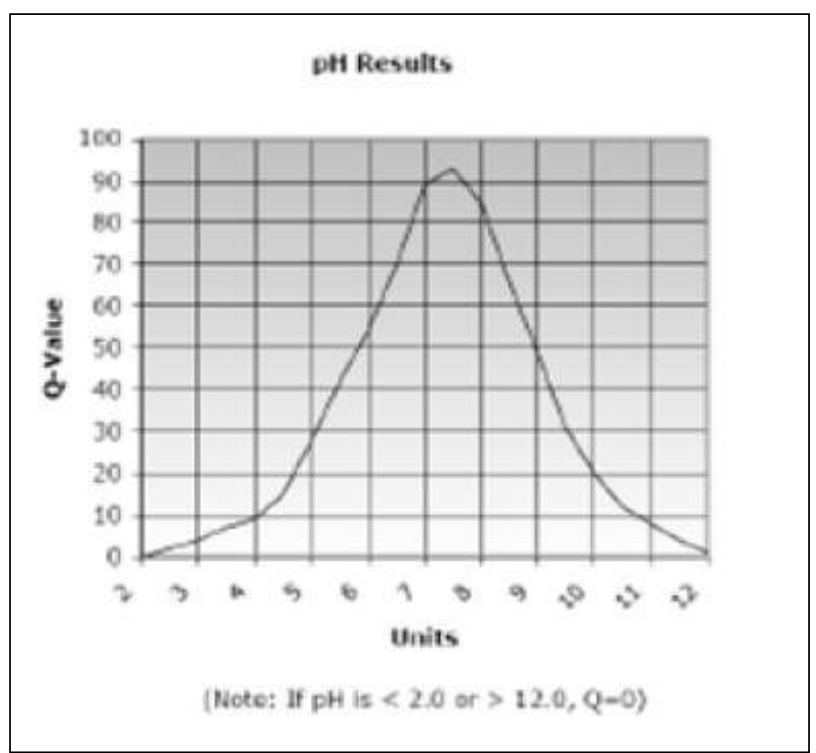

\section{GRÁFICA 6. Temperatura}

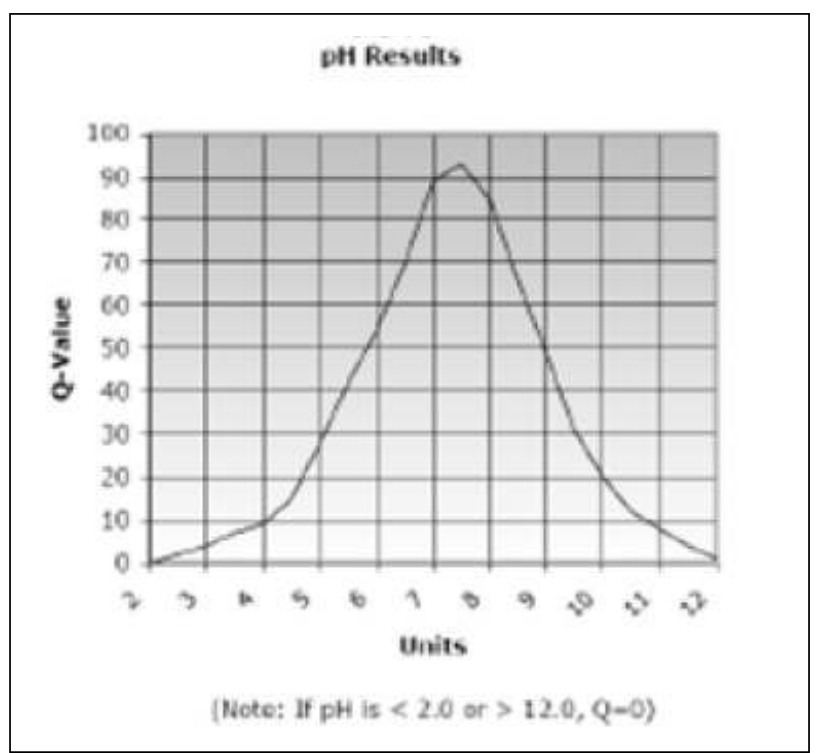




\section{GRÁFICA 7. Sólidos disueltos}

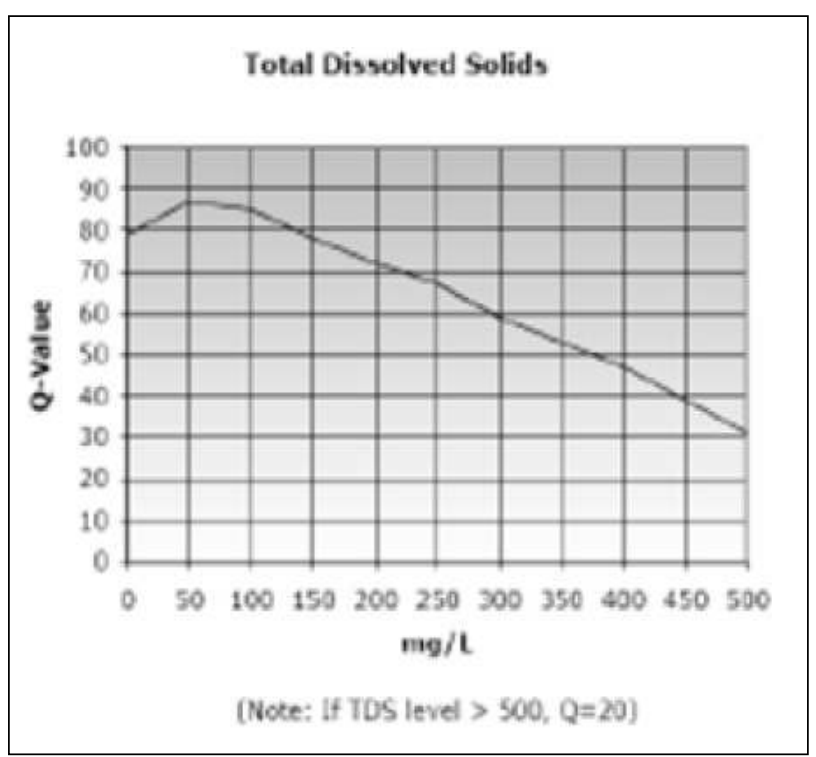

\section{GRÁFICA 9. Turbiedad}

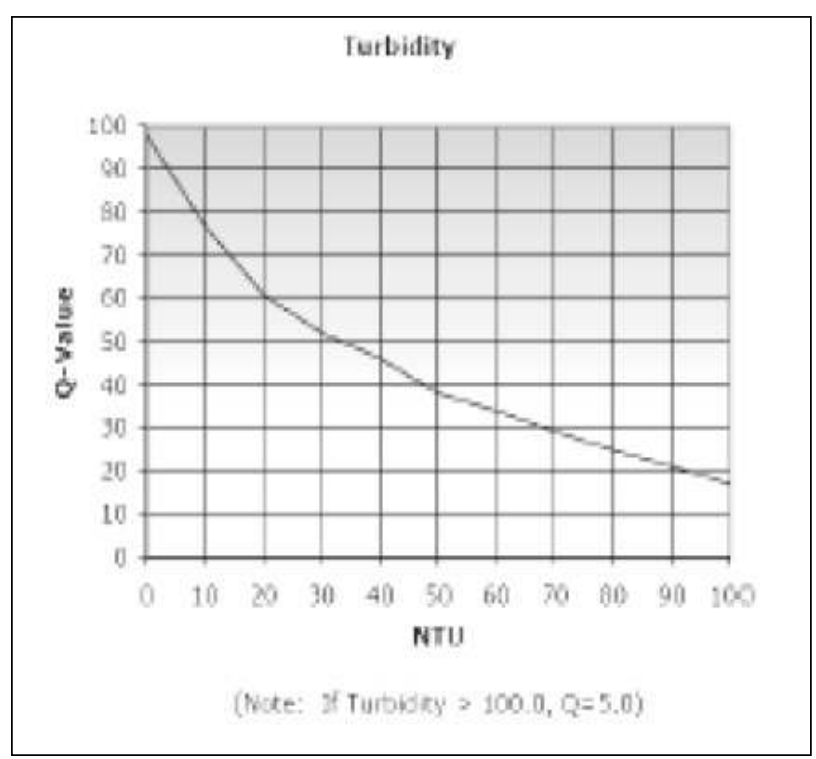

GRÁFICA 8. Fosfatos.

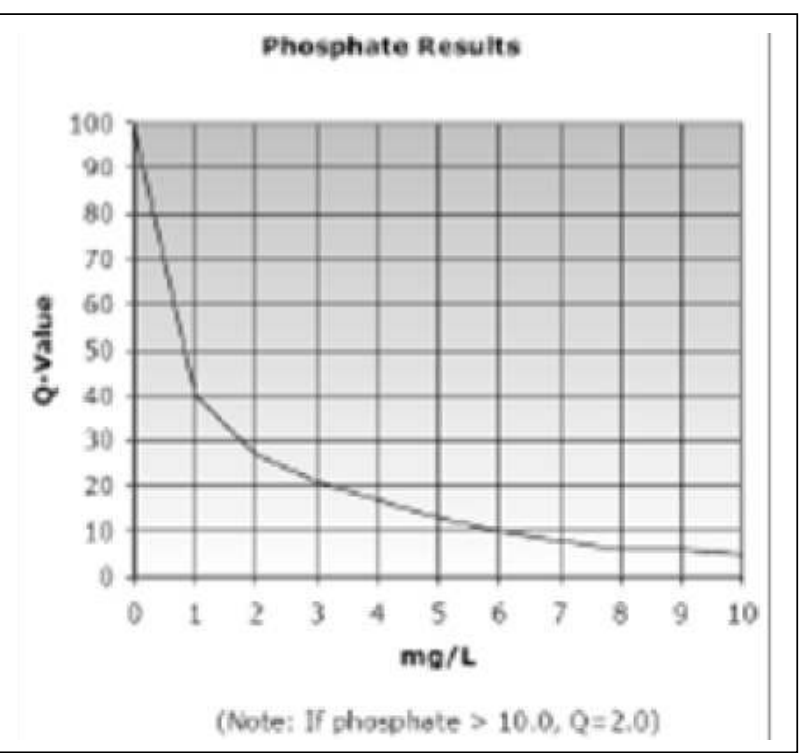

